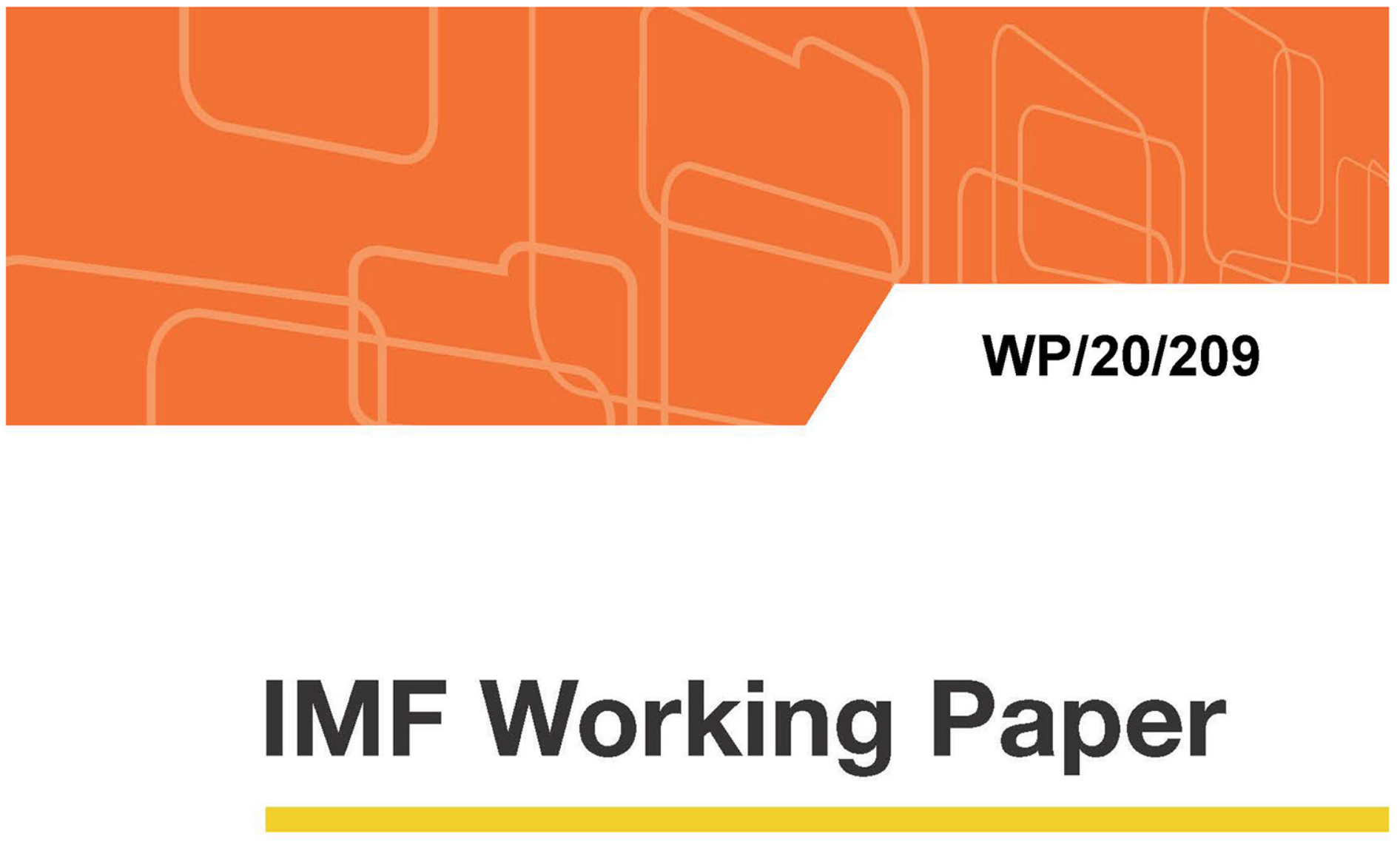

Capital Gaps, Risk Dynamics, and the Macroeconomy

by Fabian T. Lipinsky and Mirela S. Miescu

IMF Working Papers describe research in progress by the author(s) and are published to elicit comments and to encourage debate. The views expressed in IMF Working Papers are those of the author(s) and do not necessarily represent the views of the IMF, its Executive Board, or IMF management. 


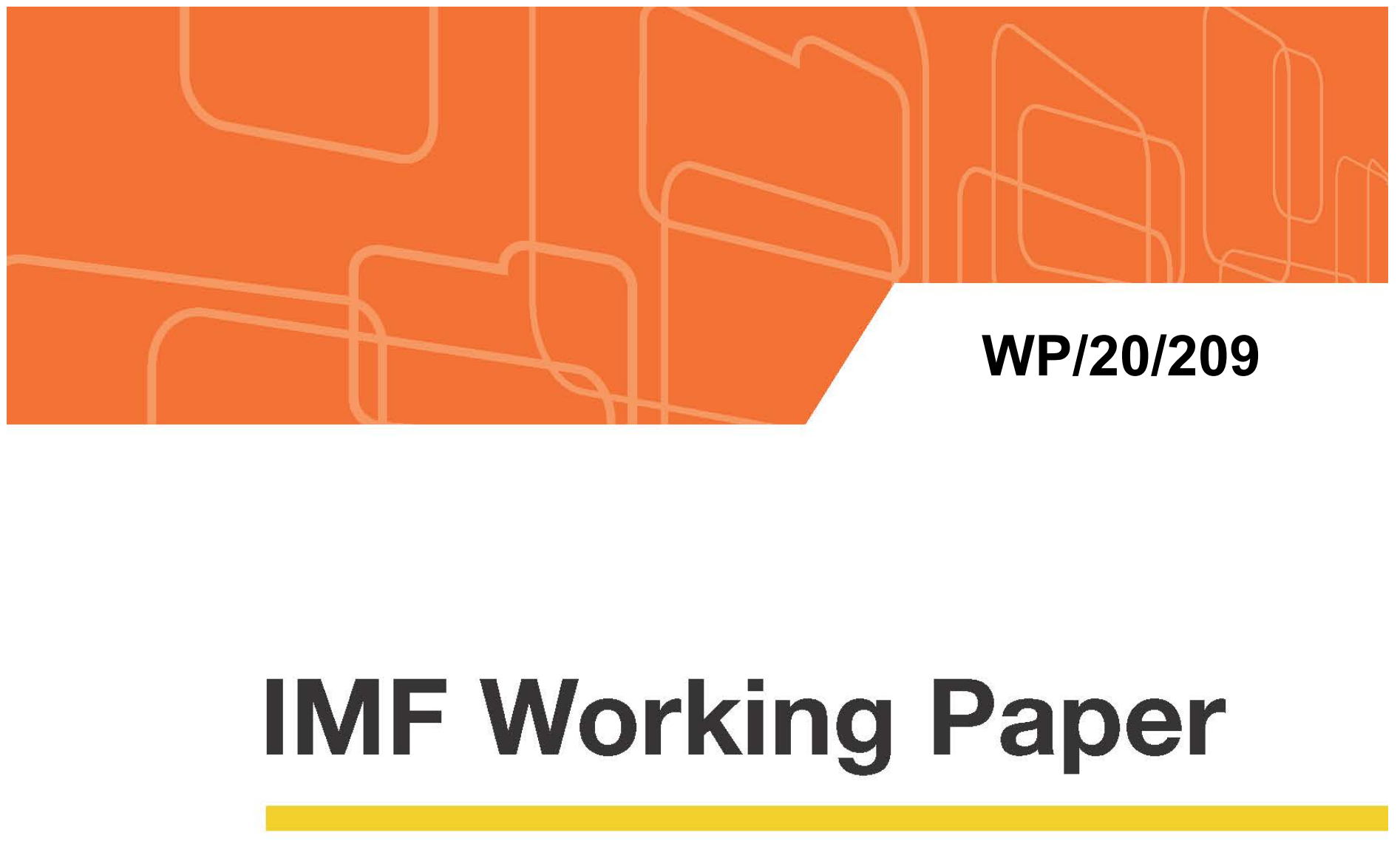

\title{
Capital Gaps, Risk Dynamics, and the Macroeconomy
}

\author{
by Fabian T. Lipinsky and Mirela S. Miescu
}

IMF Working Papers describe research in progress by the author(s) and are published to elicit comments and to encourage debate. The views expressed in IMF Working Papers are those of the author(s) and do not necessarily represent the views of the IMF, its Executive Board, or IMF management. 


\title{
IMF Working Paper
}

Monetary and Capital Markets Department

\section{Capital Gaps, Risk Dynamics, and the Macroeconomy ${ }^{1}$}

\author{
Prepared by Fabian T. Lipinsky and Mirela S. Miescu
}

Authorized for distribution by Martin Cihak

September 2020

IMF Working Papers describe research in progress by the author(s) and are published to elicit comments and to encourage debate. The views expressed in IMF Working Papers are those of the author(s) and do not necessarily represent the views of the IMF, its Executive Board, or IMF management.

\begin{abstract}
Motivated by the increasing interest in analyzing the links between the financial sector and the real economy, we develop a macro-financial structural model with two novel features. First, we include idiosyncratic and aggregate risk in a tractable general equilibrium model. This allows us to capture sectoral dynamics and the probabilities of default of both firms and financial intermediaries, and the feedback between them. Second, we introduce the concept of sticky (observed) versus flexible (agents' target) capital. The identified differences between realized and optimal values - the capital gaps of firms and banks - lead financial and business cycles, and cause gaps in credit spreads and asset prices. The model can be used as a signaling device for macroprudential intervention, and to gauge whether macroprudential action was successful ex-post (e.g., whether gaps were closed). For illustration, we show how the analysis of gaps can be applied to the U.S. economy using Bayesian estimation techniques.
\end{abstract}

JEL Classification Numbers: D81, E32, E44

Keywords: balance sheet dynamics, capital gaps, risk shocks

Author’s E-Mail Address: FLipinsky@imf.org; m.miescu@lancaster.ac.uk

${ }^{1}$ We would like to thank Martin Cihak, Tumer Kapan, Ivo Krznar, Graeme Litter, Paola Morales Acevedo, Thorvardur Tjoervi Olafsson, Francis Vitek, and Pawel Zabczyk for helpful comments on this paper. We are grateful for comments from Tobias Adrian, Nobuhiro Kiyotaki and Helene Rey on earlier versions of the paper. 


\section{Introduction}

In the aftermath of the global financial crisis (GFC) there has been increasing interest in analyzing the interconnectedness between financial sector and real economic activity. The financial turmoil propagated rapidly to the real economy causing severe disruptions in the macro-economy as well. The importance of monitoring the balance sheets of both borrowers and lenders has become clear. Increasing loan and security portfolio losses of borrowers hit balance sheets of lenders hard during the financial crisis. An increase in the uncertainty about future credit credit losses led to a repricing of risk and a deterioration in credit conditions, reflected in an increase of credit spreads and a reduction of credit. At the same time, funding conditions of lenders abruptly deteriorated. Uncertainty about financial intermediaries' balance sheet strength led to an increase in credit spreads of financial institutions and an outflow of funding, triggering a deleveraging process of financial institutions, with adverse consequences for the real economy. These facts highlight the need for a macroeconomic framework that links the balance sheet dynamics and financial conditions of both borrowers and lenders and captures the changes in uncertainty and dynamics in credit spreads.

In the face of cyclical vulnerabilities in systemic risk, such as the one experienced during the 2008 financial crisis, much attention has been dedicated to macroprudential policy tools. Identifying financial and macroeconomic variables that are performing above or below potential is one of the main challenges in setting policy ${ }^{1}$. The gaps between actual and potential performance are crucial for policy makers but are unobserved. This is especially true for financial variables such as capital and default risk of borrowers and lenders. Why do capital gaps matter? The gaps originate from cyclical fluctuations in capital of firms and financial intermediaries. During booms there is ample capital, agents increase their balance sheets, and leverage-up. However, during downturns capital declines lead to capital gaps, resulting in decreasing balance sheets and deleveraging, with adverse consequences for the macroeconomy. With capital gaps underlaying booms and busts, identifying them provides policy makers with a quantitative measure to activate macroprudential policy or other countercyclical policy measures.

The paper makes two main contributions. First, it offers a tractable general equilibrium framework that captures the joint balance sheet dynamics of borrowers and lenders (corpo-

\footnotetext{
${ }^{1}$ Throughout the paper the terms "potential", "optimal" and "target" capital are used to express the same concept.
} 
rate and financial intermediaries). We extend the framework of an influential paper presented by Christiano, Motto, and Rostagno [2014]by including financial intermediary default due to aggregate risk and we show that aggregate risk is as important as idiosyncratic (corporate) risk in driving macroeconomic and financial fluctuations. Using a simple real business cycle model (hereafter RBC) with financial frictions, we find that firm and financial intermediary leverage, as well as idiosyncratic and aggregate risk, affect capital and investment through a "macro-financial feedback factor".

Second, the paper analyzes macro-financial linkages quantitatively by measuring capital gaps of both borrowers (firms) and lenders (financial intermediaries). The gaps are computed as deviations of capital and default risk from their potential or target; specifically, the potential levels of capital and default risk are defined as the ones that agents would choose in a world where the level of capital of both firms and financial intermediary is flexible. In contrast, to determine the actual level of capital and default risk, we follow the financial accelerator literature where firms and financial intermediaries accumulate capital mostly by retaining earnings after making equity pay-outs. This approach yields similar results to models that assume adjustment costs in setting capital, as in Gourio, Kashyap, and Sim [2018]. Therefore, like the output gap between sticky and flexible prices in a monetary policy framework, capital gaps of both firms and financial intermediaries arise between sticky and flexible capital levels in our model. Calculating optimal capital levels allows us to quantify the gaps relative to realized levels.

Our approach is straightforward: we build on the financial accelerator literature and start with a model of firm balance sheet dynamics and firm default due to idiosyncratic risk. We then introduce two extensions.

The first extension consists in adding financial intermediary balance sheet dynamics and intermediary default due to aggregate risk; this extension allows us to capture the joint balance sheet dynamics of borrowers and lenders. Introducing aggregate risk, we link the probability of default of intermediaries, and their cost-of-funding and access to funds, to the aggregate risk surrounding the return on assets of non-financial firms. While we don't model liquidity explicitly, this links the access to funds of intermediaries to risk surrounding its balance sheet, introducing a rationale for intermediaries' liquidity. 
In the second extension, in addition to the benchmark solution, we derive the optimality conditions with respect to capital levels of both non-financial firms and intermediaries - agents' target levels. We then compute gaps of financial and macroeconomic variables of the economy with flexible capital relative to the economy with "sticky" capital, as in the financial accelerator literature. These gaps allow conclusions regarding which variables deviate from potential, and whether policy makers should activate macroprudential, monetary policy, or other policy tools as a corrective measure. Capital gaps can also be understood as the difference between target and realized capital levels, i.e., the difference between the capital level that borrowers and lenders should optimally aim at, and what they actually achieve. For example, in downturns, borrowers and lenders have lower levels of capital and have difficulty accessing it, but risks are highest, so indeed more capital would be required.

Our model can be used as a signaling device for macroprudential intervention (ex-ante and contemporaneous), and to gauge whether macroprudential action was successful ex-post (e.g., whether gaps were closed). Our framework is applied to the U.S. economy using Bayesian estimation techniques as in Christiano, Motto, and Rostagno [2014]. We aim to pin-down the current state of the U.S. economy, and what are the gaps at the current juncture. Second, we are interested in a historical analysis of gaps, and the driving factors behind historical movements. Specifically, our tool is well suited to answer questions such as:

(i) What shocks have driven investment, corporate credit spreads, and financial credit spreads over the last 20 years?, (ii) How risky is the non-financial corporate sector and what explains these risks?, (iii) Are credit spreads and equity prices too high or too low?, (iv) How resilient is the banking sector against adverse shocks and what are the drivers?, (v) Stress simulation: Given higher capital, would banks be more resilient if the GFC was replayed between 2019-2022, or would deleveraging occur? And should countercyclical buffers be activated?

The main findings of this paper can be summarized thus. Results suggest that (i) aggregate and idiosyncratic risk shocks have qualitatively similar effects on real and financial variables and that they are both important in driving macroeconomic fluctuations. Aggregate risks shocks are an important driver of financial credit spreads, while idiosyncratic shocks determine to a large extent corporate credit spread movements; (ii) risk in the corporate sector has recently increased due to higher idiosyncratic risk in the corporate sector. For example, such shocks 
could be linked to the weakening of the CLO/leveraged-loan market; (iii) credit spreads were too high during the financial crisis and were too low recently (i.e., prior to the COVID-19 outbreak). On the other hand, equity prices were too low during the financial crisis, and too high recently; (iv) the banking system has become more resilient following the financial crisis due to capital injections; however, it has weakened more recently due to higher equity payouts; (v) the counterfactual scenario reproducing the GFC shocks between 2019-2022 shows that capital buffers are solid; however, higher corporate risk and equity payouts make financial intermediaries vulnerable to adverse shocks that would trigger deleveraging. As a result, the countercyclical capital buffer could have been activated.

This paper is structured as follows. Section 2 reviews related literature; Section 3 describes the model; Section 4 brings the model to the data; Section 5 analyzes the results, and section 6 concludes.

\section{Literature review}

Our work is related to several streams of literature including that on the borrower and lender's balance sheet dynamics, joint balance sheet dynamics, idiosyncratic and aggregate risk shocks, and macroprudential policy and its interplay with monetary policy.

As for studies focusing on borrower balance sheet dynamics, the seminal works of Kiyotaki and Moore [1997] and Bernanke, Gertler, and Gilchrist [1998] have shown that the conditions of borrower's balance sheets matter for macroeconomic fluctuations. Christiano, Motto, and Rostagno [2014] and Gilchrist, Sim, and Zakrajšek [2014] emphasize the impact of changes in idiosyncratic risk on firms' funding conditions, while Bloom et al. [2018] analyze it without balance sheet frictions. Gourio [2013] and Bloom [2009] emphasize the impact of aggregate risk shocks, with and without balance sheet frictions. Jermann and Quadrini [2012] highlight the impact of financial shocks that tighten borrower's financing constraints. The lender balance sheet dynamics have been addressed by Gertler and Kiyotaki [2010] and Gertler, Kiyotaki, and Queralto [2012] who apply the financial accelerator mechanism of Bernanke, Gertler, and Gilchrist [1998] to financial intermediaries. Gertler and Kiyotaki [2015] further develop the model to include household liquidity shocks as described by Diamond and Dybvig [1983]. He and Krishnamurthy [2012], He and Krishnamurthy [2013], Brunnermeier and Sannikov [2014], 
and Adrian and Boyarchenko [2012] emphasize the importance of intermediaries' balance sheets, liquidity, and occasionally binding capital constraints. Nuño and Thomas [2017] highlight the importance of changes in aggregate risk while Olafsson [2018] models cross-borders macrofinancial linkages in a small open economy framework.

The paper, probably closest to ours is Gourio, Kashyap, and Sim [2018], which applied the framework of Gourio [2013] to financial institutions and introduces adjustment cost in setting the capital structure. This framework was developed simultaneously to ours. We contribute to the literature by (i) analyzing the joint balance sheet dynamics of both borrowers and lenders, (ii) estimating the model, (iii) identifying both idiosyncratic and aggregate risk and its relative contributions, and (iv) computing capital gaps for the U.S. economy (and drawing concrete conclusions based on the application to the data).

There is a large literature modelling the failure of financial institutions ${ }^{2}$. Default in this literature is often related to idiosyncratic risk associated to financial institutions. We contribute to this stream of literature by analyzing financial sector default due to aggregate risk.

Finally there is a growing literature that studies the role of macroprudential policy. Starting with Lorenzoni [2008], a large body of literature has emerged that examines bank regulation in a macro-economic setting. As pointed out by Gertler, Kiyotaki, and Prestipino [2019], "this work has been both qualitative (e.g., Angeloni and Faia [2013], Jeanne and Korinek [2014], Kehoe and Midrigan [2015]) and quantitative (e.g., Bianchi and Mendoza [2018], Benigno et al. [2013], and Begenau and Landvoigt [2018])". While the need for macroprudential policies arises in the macroprudential literature often by a non-internalized externality, the gaps identified in our paper result from differences between the actual and targeted levels of capital, like the monetary policy concept of flexible versus sticky prices.

\section{Model Description}

There are six agents in the economy: households, final good firms, (entrepreneurial) firms, financial intermediaries, mutual funds, and the government. Firms, financial intermediaries, and mutual funds build the financial system and represent the innovative part of the model.

\footnotetext{
${ }^{2}$ For example, see Krasa and Villamil [1992], Hirakata, Sudo, and Ueda [2011], Hirakata, Sudo, and Ueda [2013], Zeng [2013], Benes and Kumhof [2011], and Jin and Zeng [2011].
} 
Households, final good firms, and the government build the real economy, or the standard part of the model.

The financial system is central to the entire system dynamics. The setup is summarized here, followed by a detailed description in the following sections. Households own firms, financial intermediaries, and mutual funds that maximise expected future cash-flows on behalf of households. More specifically, households inject equity into firms and financial intermediaries respectively, funding in mutual funds, and receive the earnings. The funds invested in firms and intermediaries are equal to $n_{F, t}$ and $n_{B, t}$, consisting of a fixed equity injection $\omega_{F}$ and $\omega_{B}$ and a flexible fraction $z_{u, t}\left(1-\gamma_{F}\right)$ and $z_{k, t}\left(1-\gamma_{B}\right)$ of earnings, respectively. These are subject to pay-out shocks $z_{u, t}$ and $z_{k, t}$, for firms and financial intermediaries. Funding $d_{t}$ is provided to mutual funds. In return, households receive the fraction of earnings not injected as dividends as well as income from mutual funds. Consequently, firms and financial intermediaries invest equity $n_{F, t}$ and $n_{B, t}$, and mutual funds funding $d_{t}$. Regarding the flows between financial agents, mutual funds provide funding to financial intermediaries. Financial intermediaries combine equity $n_{B, t}$ and received funding $d_{t}$ to provide commercial loans $b_{t}$ to firms $\left(n_{B, t}+d_{t}=b_{t}\right)$. Firms invest equity $n_{F, t}$ and loans $b_{t}$ in productive assets $k_{t}$, valued at price $q_{t}\left(n_{F, t}+b_{t}=q_{t} k_{t}\right)$. Altogether, this implies that the invested funds in the financial sector are ultimately invested in productive assets, defined as $n_{F, t}+n_{B, t}+d_{t}=q_{t} k_{t}$ (see Figure 1). The financial sector injections and payments received are included in the household's problem by outlays equal to $q_{t} k_{t}$ and income equal to $F_{t} R_{k, t} k_{t-1}$, as explained below.

The real economy part of the model is standard; the household problem is described in detail below. The final good firms rent productive assets $k_{t}$ from (entrepreneurial) firms and hire household workers $n_{t}$ to produce output $y_{t}$. Households use the income from working $w_{t} n_{t}$ and all other income to invest in financial assets, government bonds $b_{t}^{g}$ and financial system injections $q_{t} k_{t}$, and consume $c_{t}$.

Regarding the government, it ultimately finances exogenous spending $g_{t}$ with funds from government bonds $b_{t}^{g}$ held by households and lump-sum taxes from households, and taxes income of firms and financial intermediaries at rate $\tau$. The various payments and receivables culminate in the familiar market clearing condition $c_{t}+i_{t}+g_{t}=y_{t}$. 
Figure 1: Diagram of the model

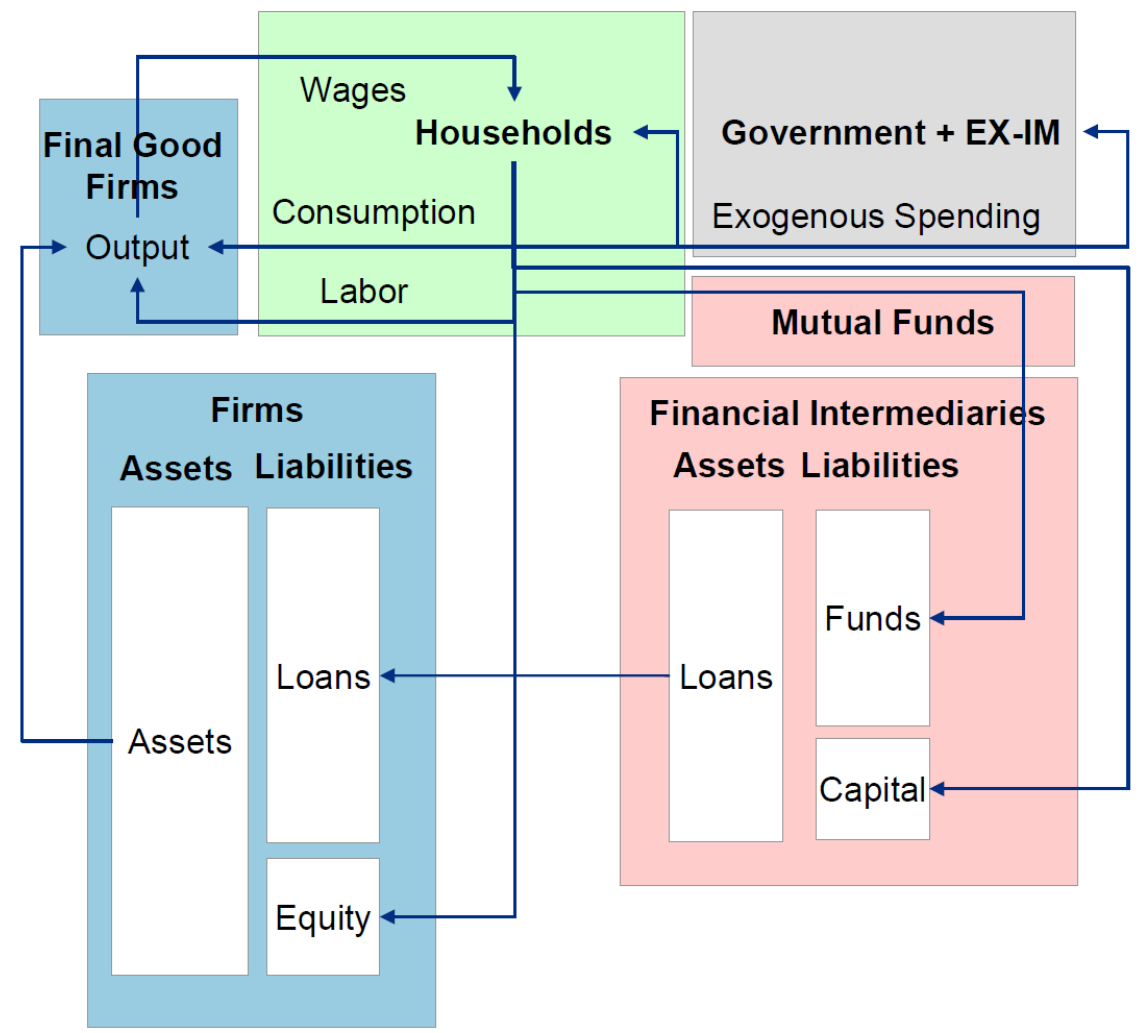

\section{Households}

There is a representative household that maximizes lifetime utility, $E_{0} \sum_{t=0}^{\infty} \beta^{t} U_{t}$ subject to a budget constraint. The utility function takes the standard CRRA form, while $h>0$ captures internal habit formation. The household sends $n_{t}$ members to work. It derives utility from consumption $c_{t}$ and dis-utility from sending members to work (or utility from home production), while $z_{n, t}$ is a labor disutility shock and $\tau_{n}$ a cost parameter.

$$
\begin{gathered}
\max L=E_{0} \sum_{t=0}^{\infty} \beta^{t}\left[\frac{\left(c_{t}-h c_{t-1}\right)^{1-\sigma}}{(1-\sigma)}-\frac{z_{n, t} \tau_{n} n_{t}^{1+\Phi}}{1+\phi}\right] \\
-\lambda_{t}\left[c_{t}+q_{t} k_{t}+b_{t}^{g}-\left(F_{t} R_{k, t} k_{t-1}+w_{t} n_{t}+R_{t-1} b_{t-1}^{g}+q_{t} i_{t}-i_{t}\left(1+S\left(z_{i, t} \frac{i_{t}}{i_{t-1}}\right)\right)+\Pi_{t}\right)\right]
\end{gathered}
$$

The household consumes $c_{t}$, invests $b_{t}^{g}$ in government bonds, and invests funds $q_{t} k_{t}$ in firms. It receives labor income at the wage rate $w_{t}$ from each member that is working, receives the gross risk-free rate $R_{t-1}$ on government bonds, and earns income $R_{k, t}$ on invested assets. It 
should be emphasized that the return on capital of households is discounted by the term $F_{t}$ which captures the interactions between firms, financial intermediaries, and the real economy. The term is called the "macro-financial feedback factor" and is derived in the financial sector optimization problem (see equation 45). The household also produces capital and earns $q_{t} i_{t}$ from selling capital at cost $S$ of producing capital. The function $S$ denotes the capital adjustment cost function, while $z_{i, t}$ is the investment adjustment cost shock. Last, the household consolidates all sectors and pays lump-sum taxes, such that the budget constraint results in the economy's market-clearing condition (equation 14), as in Gourio [2013].

The first order conditions with respect to capital $k_{t}$, government bonds $b_{t}^{g}$, labor $n_{t}$, consumption $c_{t}$, and investment $i_{t}$ are:

$$
\begin{gathered}
\partial k_{t}:-q_{t}+\beta E_{t}\left[\frac{\lambda_{t+1}}{\lambda_{t}} F_{t+1} R_{k, t+1}\right]=0 \\
R_{k, t}=r_{k, t}+(1-\delta) q_{t}
\end{gathered}
$$

$$
\partial b_{t}:-1+\beta E_{t}\left[\frac{\lambda_{t+1}}{\lambda_{t}} R\right]=0
$$

$$
\partial n_{t}:-z_{n, t} \tau n_{t}^{\phi}+\lambda_{t} w_{t}=0
$$

$$
\partial c_{t}:\left(c_{t}-h c_{t-1}\right)^{-\sigma}-h \beta E_{t}\left[\left(c_{t+1}-h c_{t}\right)^{-\sigma}\right]-\lambda_{t}=0
$$

$\partial i_{t}: \quad q_{t}-\left(1+S\left(z_{i, t} \frac{i_{t}}{i_{t-1}}\right)+S^{\prime}\left(z_{i, t} \frac{i_{t}}{i_{t-1}}\right) z_{i, t} \frac{i_{t}}{i_{t-1}}\right)+\beta E_{t}\left[\frac{\lambda_{t+1}}{\lambda_{t}} S^{\prime}\left(z_{i, t+1} \frac{i_{t+1}}{i_{t}}\right) z_{i, t+1}\left(\frac{i_{t+1}}{i_{t}}\right)^{2}\right]=0$

$$
S\left(z_{i, t} \frac{i_{t}}{i_{t-1}}\right)=\frac{\phi_{i}}{2}\left(z_{i, t} \frac{i_{t}}{i_{t-1}}-1\right)^{2}
$$

The first order conditions are those of a simple RBC model with habits $h$ in consumption, and capital adjustment cost $S$, with one exception. The macro-financial feedback factor $F_{t+1}$ 
enters the first-order condition with respect to capital due to financial frictions. For later purposes, we define the stochastic discount factor of the household $M_{t+1}$ as:

$$
M_{t+1}=\beta\left[\frac{\lambda_{t+1}}{\lambda_{t}}\right]
$$

Final good firms rent capital and hire workers.

$$
\begin{gathered}
\max \left\{y_{t}-r_{t} k_{t-1}-w_{t} n_{t}\right\} \\
y_{t}=k_{t-1}{ }^{\alpha}\left(z_{y, t} n_{t}\right)^{1-\alpha}
\end{gathered}
$$

The first order conditions with respect to capital and labor yield equations for the return on capital $r_{t}$ and wages $w_{t}$ :

$$
\begin{gathered}
\partial k_{t-1}: \quad r_{t}=\alpha \frac{y_{t}}{k_{t-1}} \\
\partial n_{t}: \quad w_{t}=(1-\alpha) \frac{y_{t}}{n_{t}}
\end{gathered}
$$

The market-clearing condition is:

$$
c_{t}+i_{t}+g_{t}=y_{t}
$$

where $g_{t}$ denotes exogenous spending.

\section{Firms}

Firms finance assets $q_{t} k_{t}$ with equity $n_{F, t}$ and debt $b_{t}$ from one of the intermediaries. Next period, firms receive a return on invested assets $R_{k, t+1}$ and pay back debt at rate $R_{b, t}=1+i_{b, t}$. The return on assets is subject to an idiosyncratic $\left(\epsilon_{i, t+1}\right)$ and aggregate $\left(z_{t+1}\right)$ productivity shock.

Based on Christiano, Motto, and Rostagno [2014] we introduce idiosyncratic risk, and add aggregate risk, which turns out to drive intermediary default. Specifically, we model idiosyn- 
cratic (corporate) and aggregate risk by assuming that firms purchase $k_{t}$ units of capital at time $\mathrm{t}$, and transform them in $z_{t+1} \varepsilon_{i, t+1} k_{t}$ units of effective capital. The realization of the variables $\varepsilon_{i, t+1}$ and $z_{t+1}$ is uncertain ex ante. They are independently distributed log normal random variables, normalized to have unit means. While $\varepsilon_{i, t+1}$ differs among firms, $z_{t+1}$ is an aggregate shock experienced by all firms and financial intermediaries. Large values of $z_{t+1}$ imply a high productivity level overall. Large values of $\varepsilon_{i, t+1}$ mean success of a firm compared to other firms, while a low value means failure. Idiosyncratic differences may in fact be large. We denote the standard deviation of $\log \left(z_{t}\right)$ and $\log \left(\varepsilon_{i, t}\right)$ with $\sigma_{z, t}$ and $\sigma_{\varepsilon, t}$, respectively. Shocks to the law of motion of these standard deviations represent our idiosyncratic and aggregate risk shocks and can be interpreted as systemic (aggregate) and credit (idiosyncratic or corporate) risk shocks, respectively.

Firms income is taxed at rate $\tau$, and future cash-flows are discounted at the stochastic discount factor $M_{t+1}$ of households, who own the firms.

$$
-n_{F, t}+E_{t}\left(M_{t+1} \max \left(\left(z_{t+1} \epsilon_{i, t+1} R_{k, t+1} k_{t}-R_{b, t} b_{t}\right)(1-\tau), 0\right)\right)
$$

Firms default if the value of end-of-period assets falls below the value of liabilities, or if their idiosyncratic productivity $\epsilon_{i, t+1}$ falls below a certain default threshold $\epsilon_{t+1}^{z}$.

$$
\epsilon_{i, t+1}<\epsilon_{t+1}^{z} \equiv \frac{R_{b, t} b_{t}}{z_{t+1} R_{k, t+1} k_{t}}
$$

The probability of default of firms depends on their balance sheet strength, aggregate productivity, and the cumulative distribution function of idiosyncratic productivity denoted by the F function.

$$
P D^{F}\left(\epsilon_{t+1}^{z}\right)=\operatorname{Prob}\left(\epsilon_{i, t+1}<\epsilon_{t+1}^{z}\right)=F\left(\epsilon_{t+1}^{z}, \sigma_{\epsilon, t+1}\right)
$$

Some useful notation can help rewrite firms' cash flow as the integral over idiosyncratic risk:

$$
\begin{aligned}
& -n_{F, t}+E_{t}\left(M_{t+1}\left(\int_{\epsilon_{t+1}^{z}}^{\infty}\left(z_{t+1} \epsilon_{i, t+1} R_{k, t+1} k_{t}-R_{b, t} b_{t}\right) f\left(\epsilon_{i, t+1}\right) d\left(\epsilon_{i, t+1}\right)\right)(1-\tau)\right) \\
& -n_{F, t}+E_{t}\left(M_{t+1}\left(z_{t+1} R_{k, t+1} k_{t}\left(1-\Delta\left(\epsilon_{t+1}^{z}\right)\right)-R_{b, t} b_{t}\left(1-F\left(\epsilon_{t+1}^{z}\right)\right)\right)(1-\tau)\right)
\end{aligned}
$$




$$
-n_{F, t}+E_{t}\left(M_{t+1}\left(z_{t+1} R_{k, t+1} k_{t}\left(1-\Gamma\left(\epsilon_{t+1}^{z}\right)\right)\right)(1-\tau)\right)
$$

where

$$
\begin{gathered}
\Delta\left(\epsilon_{t+1}^{z}\right) \equiv \int_{0}^{\epsilon_{t+1}^{z}} \epsilon_{i, t+1} f\left(\epsilon_{i, t+1}\right) d\left(\epsilon_{i, t+1}\right) \\
\Gamma\left(\epsilon_{t+1}^{z}\right) \equiv \Delta\left(\epsilon_{t+1}^{z}\right)+\epsilon_{t+1}^{z}\left(1-F\left(\epsilon_{t+1}^{z}\right)\right)
\end{gathered}
$$

Due to debt-financing, firms retain a share equal to $1-\Gamma\left(\epsilon_{t+1}^{z}\right)$ of total earnings.

\section{Financial Intermediaries}

Financial intermediaries (hereafter FIs) finance loans $b_{t}$ with capital $n_{B, t}$ and funding $d_{t}$ received from mutual funds $\left(b_{t}=n_{B, t}+d_{t}\right)$. Next period, FIs receive a return on the loan portfolio $R_{B, t+1}$ on the $b_{t}$ loans provided to firms, and pay back received funding at rate $R_{d, t}=1+i_{d, t}$. The expected cashflow of the FIs is:

$$
-n_{B, t}+E_{t}\left(M_{t+1} \max \left(\left(R_{B, t+1} b_{t}-R_{d, t} d_{t}\right)(1-\tau), 0\right)\right)
$$

If the value of assets falls below the value of liabilities $\left(R b_{t}<R_{d, t} d_{t}\right)$ the FI defaults and receives zero, protected by limited liability. The return on the loan portfolio consists of two parts. FIs receive the interest and principal payment from non-defaulting firms and recover the assets from defaulted firms. Default triggers a cost cut equal to a fraction $\mu$ of firms' earnings.

$$
R_{B, t+1} b_{t} \equiv R_{b, t} b_{t}\left(1-F\left(\epsilon_{i, t+1}^{z}\right)\right)+\int_{0}^{\epsilon_{t+1}^{z}} z_{t+1} \epsilon_{i, t+1} R_{k, t+1} k_{t} f\left(\epsilon_{i, t+1}\right) d\left(\epsilon_{i, t+1}\right)(1-\mu)
$$

FIs' cash flow can be rewritten:

$$
-n_{B, t}+E_{t}\left(M_{t+1} \max \left(\left(z_{t+1} R_{k, t+1} k_{t}\left(\Gamma\left(\epsilon_{t+1}^{z}\right)-\mu \Delta\left(\epsilon_{t+1}^{z}\right)\right)-R_{d, t} d_{t}\right)(1-\tau), 0\right)\right)
$$

FIs receive a share $\Gamma\left(\epsilon_{t+1}^{z}\right)$ of firms' earnings minus screening costs. FIs default if the value of end-of-period assets falls below the value of liabilities, or if aggregate productivity $z_{t+1}$ falls below default threshold $z_{t+1}^{*}$ 


$$
z_{t+1}<z_{t+1}^{*}
$$

such that

$$
z_{t+1}^{*} R_{k, t+1} k_{t}\left(\Gamma\left(\epsilon_{t+1}^{*}\right)-\mu \Delta\left(\epsilon_{t+1}^{*}\right)\right)-R_{d, t} d_{t}=0
$$

The introduction of a financial intermediary default threshold is the main addition to Christiano, Motto, and Rostagno [2014] and adds default of financial institutions to the framework. Hence, the probability of default of FIs depends on the balance sheet strength of borrowers and FIs and the distribution function of aggregate productivity.

$$
P D^{B}\left(z_{t+1}^{*}\right)=\operatorname{Prob}\left(z_{t+1}<z_{t+1}^{*}\right)=G\left(z_{t+1}^{*}, \sigma_{z, t+1}\right)
$$

To differentiate normal states of the world from states in which FIs default, we assume that productivity is lower in cases of default. Specifically, there is a large number of FIs, each serving a part of the economy. If default of an FI occurs, the part of the economy that is served by this FI experiences a credit crunch, and factors of production are not optimally allocated any more. For simplicity it is assumed that aggregate productivity takes a fixed value above and below the default threshold $z_{t+1}^{*}$ equal to $z^{N}$, and $z^{D}$, respectively, depending on whether default occurs. Therefore, aggregate productivity of any part of the economy served by an FI has only three realizations.

Case 1 (no default): With probability $\left(1-G\left(z_{t+1}^{*}\right)\right)$, FIs do not default, under "normal" circumstances. Productivity and firms' default threshold take on the following values:

$$
\left(z_{t+1}>z_{t+1}^{*}\right) \rightarrow z_{t+1}=z^{N} \rightarrow \epsilon_{t+1}^{N} \equiv \frac{R_{b, t} b_{t}}{z^{N} R_{k, t+1} k_{t}}
$$

Case 2 (default threshold): The asset value of an intermediary is equal to its liabilities.

$$
z_{t+1}^{*} R_{k, t+1} k_{t}\left(\Gamma\left(\epsilon_{t+1}^{*}\right)-\mu \Delta\left(\epsilon_{t+1}^{*}\right)\right)-R_{d, t} d_{t}=0
$$




$$
z_{t+1}=z_{t+1}^{*} \rightarrow \epsilon_{t+1}^{*} \equiv \frac{R_{b, t} b_{t}}{z_{t+1}^{*} R_{k, t+1} k_{t}}
$$

Case 3 (default): With probability $G\left(z_{t+1}^{*}\right)$, financial intermediaries default. Productivity and firms' default threshold take on the following values:

$$
\left(z_{t+1}<z_{t+1}^{*}\right) \rightarrow z_{t+1}=z^{D} \rightarrow \epsilon_{t+1}^{D} \equiv \frac{R_{b, t} b_{t}}{z^{D} R_{k, t+1} k_{t}}
$$

Given this setup, each period a fraction $G\left(z_{t}^{*}\right)$ of FIs defaults and productivity in this part of the economy is $z^{D}$, while the majority of FIs, equal to a share $1-G\left(z_{t}^{*}\right)$ of FIs, survives with a productivity equal to $z^{N}$.

After introduction of the different households, the financial intermediary objective function becomes:

$$
-n_{B, t}+E_{t}\left(M_{t+1}\left(z^{N} R_{k, t+1} k_{t}\left(\Gamma\left(\epsilon_{t+1}^{N}\right)-\mu \Delta\left(\epsilon_{t+1}^{N}\right)\right)-R_{d, t} d_{t}\right)\left(1-G\left(z_{t+1}^{*}\right)\right)(1-\tau)\right)
$$

\section{Mutual Funds}

Mutual funds lend funds $d_{t}$ to FIs. In "normal" times they get back principal plus interest. If a FI defaults, they receive the intermediary's assets minus cost of default equal to fraction $\mu_{B}$.

$$
\begin{gathered}
-d_{t}+E_{t}\left(M_{t+1}\left(R_{d, t} d_{t}\left(1-G\left(z_{t+1}^{*}\right)\right)+G\left(z_{t+1}^{*}\right) R_{k, t+1} k_{t} s_{B, t+1}^{D}\left(1-\mu_{B}\right)\right)\right) \\
s_{B, t+1}^{D}=z^{D}\left(\Gamma\left(\varepsilon_{t+1}^{D}\right)-\mu \Delta\left(\varepsilon_{t+1}^{D}\right)\right)
\end{gathered}
$$

While gains of FIs are taxed, mutual funds don't pay taxes. This results in a net benefit of financial intermediation equal to $\tau R_{d, t} d_{t}\left(1-G\left(z_{t+1}^{*}\right)\right)$, serving as an offset against the cost of default. We now have all the ingredients to solve the agents' optimization problem. 


\section{Optimization Problem}

The objective functions (or expected cashflows) of firms, FIs, and mutual funds are tied together in one optimization problem. Firms maximize expected cashflow subject to a zero-profit condition for FIs and mutual funds. Firms have an initial outlay of own funds $n_{F, t}$ and raise debt $b_{t}$ from FIs to acquire assets $q_{t} k_{t}=n_{F, t}+b_{t}$. FIs invest capital $n_{B, t}$ and raise funding $d_{t}$ from mutual funds to provide lending $b_{t}=n_{B, t}+d_{t}$. This implies:

$$
q_{t} k_{t}=n_{F, t}+n_{B, t}+d_{t}
$$

Due to debt financing, firms receive share $s$ of earnings, and pay the remainder to FIs. Firms' cashflow depends on whether the intermediary defaults. Intermediaries default with probability $G$, which means that aggregate productivity falls from $z^{N}$ ("normal times") to $z^{D}$ (default), i.e., $z^{D}<z^{N}$. FIs receive their share in the earnings and pay back mutual funds in "normal" times as long as assets are greater than liabilities. In case of default, payment ceases, and mutual funds can claim the assets of the intermediary.

The objective of firms is to maximize its expected cashflow, with respect to $d_{t,} R_{d, t,}, z_{t+1}^{*}$ and $R_{b, t}$

$\max L=-n_{F, t}+E_{t}\left(M_{t+1} \frac{R_{k, t+1}}{q_{t}}\left(n_{F, t}+n_{B, t}+d_{t}\right)\left(s_{F, t+1}^{N}\left(1-G\left(z_{t+1}^{*}\right)\right)+s_{F, t+1}^{D} G\left(z_{t+1}^{*}\right)\right)\right)(1-\tau)$

$$
\begin{aligned}
& s_{F, t+1}^{N}=z^{N}\left(1-\Gamma\left(\epsilon_{t+1}^{N}\right)\right) \\
& s_{F, t+1}^{D}=z^{D}\left(1-\Gamma\left(\epsilon_{t+1}^{D}\right)\right)
\end{aligned}
$$

subject to:

(i) the zero-profit condition for FIs (net present value of zero), 


$$
\begin{gathered}
+\lambda_{t}^{B}\left[-n_{B, t}+E_{t}\left(M_{t+1}\left(\frac{R_{k, t+1}}{q_{t}}\left(n_{F, t}+n_{B, t}+d_{t}\right) s_{B, t+1}^{N}-R_{d, t} d_{t}\right)\left(1-G\left(z_{t+1}^{*}\right)\right)\right)(1-\tau)\right] \\
s_{B, t+1}^{N}=z^{N}\left(\Gamma\left(\epsilon_{t+1}^{N}\right)-\mu \Delta\left(\epsilon_{t+1}^{N}\right)\right)
\end{gathered}
$$

(ii) the default threshold of FIs (when assets equal liabilities),

$$
\begin{gathered}
+E_{t}\left(M_{t+1} \lambda_{t+1}^{V}\left(\frac{R_{k, t+1}}{q_{t}}\left(n_{F, t}+n_{B, t}+d_{t}\right) s_{B, t+1}^{*}-R_{d, t} d_{t}\right)\right) \\
s_{B, t+1}^{*}=z_{t+1}^{*}\left(\Gamma\left(\epsilon_{t+1}^{*}\right)-\mu \Delta\left(\epsilon_{t+1}^{*}\right)\right)
\end{gathered}
$$

and (iii) the zero-profit condition of financial intermediary investors (e.g., mutual funds).

$$
+\lambda_{t}^{I}\left[-d_{t}+E_{t}\left(M_{t+1}\left(R_{d, t} d_{t}\left(1-G\left(z_{t+1}^{*}\right)\right)+G\left(z_{t+1}^{*}\right) \frac{R_{k, t+1}}{q_{t}}\left(n_{F, t}+n_{B, t}+d_{t}\right) s_{B, t+1}^{D}\left(1-\mu_{B}\right)\right)\right)\right]
$$

$$
s_{B, t+1}^{D}=z^{D}\left(\Gamma\left(\epsilon_{t+1}^{D}\right)-\mu \Delta\left(\epsilon_{t+1}^{D}\right)\right)
$$

\section{Financial Frictions}

There are two main frictions in the model. First, payments of firms and FIs are taxed (taxrate of $\tau$ ), while payments of mutual funds are not. This friction could also represent differences in agents' discount factor. It results in a benefit of financial intermediation equal to $\tau R_{d, t} d_{t}\left(1-G\left(z_{t+1}^{*}\right)\right)$. Taking into account FIs default threshold $z_{t+1}^{*} R_{k, t+1} k_{t}\left(\Gamma\left(\varepsilon_{t+1}^{*}\right)-\mu \Delta\left(\varepsilon_{t+1}^{*}\right)\right)-$ 
$R_{d, t} d_{t}=0$, it becomes clear that $z_{t+1}^{*}$ and $R_{d, t} d_{t}$ are chosen to find the optimal trade-off between a higher benefit of financial intermediation and the cost of increasing the likelihood of

FI default $G^{\prime}\left(z_{t+1}^{*}\right)=g\left(z_{t+1}^{*}\right)$. Second, firm default triggers a cost equal to a fraction $\mu$ of firms' earnings. Consequently, $R_{b, t} b_{t}$ is chosen as the optimal trade-off between the benefit of financial intermediation, increasing $\Gamma\left(\varepsilon_{t+1}^{*}\right)-\mu \Delta\left(\varepsilon_{t+1}^{*}\right)$, while causing a higher cost of default.

\section{Optimization}

We receive the following first order conditions with respect to $d_{t}, \Phi_{D, t}, z_{t+1}^{*}$, and $\Phi_{B, t}$, denoting with $\Phi_{D, t}, \equiv \frac{R_{D, t} d_{t}}{k_{t}}$ and $\Phi_{B, t}, \equiv \frac{R_{B, t} b_{t}}{k_{t}}$, while $s_{F, t+1}^{N}$ and $s_{F, t+1}^{D}$ capture the share of retained earnings of firms in normal and defaulting times, respectively (as per equations 36 and 37):

$$
\partial d_{t}: \quad \lambda_{t}^{I}=E_{t}\left(M_{t+1} \frac{R_{k, t+1}}{q_{t}} X_{t+1}\right)
$$

where

$$
\begin{gathered}
X_{t+1} \equiv\left(s_{F, t+1}^{N}\left(1-G\left(z_{t+1}^{*}\right)\right)+s_{F, t+1}^{D} G\left(z_{t+1}^{*}\right)\right)(1-\tau)+\lambda_{t}^{B} s_{B, t+1}^{N}\left(1-G\left(z_{t+1}^{*}\right)\right)(1-\tau) \\
\quad+\lambda_{t}^{I} s_{B, t+1}^{D} G\left(z_{t+1}^{*}\right)\left(1-\mu_{B}\right)+\left(\lambda_{t}^{I}-\lambda_{t}^{B}(1-\tau)\right) s_{B, t+1}^{*}\left(1-G\left(z_{t+1}^{*}\right)\right)
\end{gathered}
$$

The macro-financial feedback factor can now be identified as $F_{t+1} \equiv X_{t+1} / \lambda_{t}^{I}$. It depends on firm and intermediary leverage as well as on idiosyncratic and aggregate risk. Firms choose the remaining variables to maximize it.

$$
\partial \phi_{D, t}: \quad E_{t}\left(M_{t+1}\left(\left(\lambda_{t}^{I}-\lambda_{t}^{B}(1-\tau)\right)\left(1-G\left(z_{t+1}^{*}\right)\right)-\lambda_{t+1}^{V}\right) k_{t}-A^{\prime}\left(\phi_{D, t}\right)\right)=0
$$

Firms choose FI leverage trading off the benefit of financial intermediation $\tau\left(1-G\left(z_{t+1}^{*}\right)\right)$ versus tightening of the constraint $\lambda_{t+1}^{V}$.

$$
\partial z_{t+1}^{*}\left(s_{t+1}\right): \quad-g\left(z_{t}^{*}\right) Z_{t}+\lambda_{t}^{V}\left(\Gamma\left(\epsilon_{t}^{*}\right)-\mu \Delta\left(\epsilon_{t}^{*}\right)+z_{t}^{*} \frac{\partial \epsilon_{t}^{*}}{\partial z_{t}^{*}} \frac{\partial\left(\Gamma\left(\epsilon_{t}^{*}\right)-\mu \Delta\left(\epsilon_{t}^{*}\right)\right)}{\partial \epsilon_{t}^{*}}\right)=0
$$


where

$$
Z_{t} \equiv\left(s_{F, t}^{N}-s_{F, t}^{D}\right)(1-\tau)+\lambda_{t-1}^{B} s_{B, t}^{N}(1-\tau)-\lambda_{t-1}^{I} s_{B, t}^{D}\left(1-\mu_{B}\right)+\left(\lambda_{t-1}^{I}-\lambda_{t-1}^{B}(1-\tau)\right) s_{B, t}^{*}
$$

Substituting:

$$
\begin{gathered}
\Gamma\left(\epsilon_{t}^{*}\right)=\Delta\left(\epsilon_{t}^{*}\right)+\epsilon_{t}^{*}\left(1-F\left(\epsilon_{t}^{*}\right)\right) \\
\frac{\partial \epsilon_{t}^{*}}{\partial z_{t}^{*}}=-\frac{\epsilon_{t}^{*}}{z_{t}^{*}} \\
\frac{\partial\left(\Gamma\left(\epsilon_{t}^{*}\right)-\mu \Delta\left(\epsilon_{t}^{*}\right)\right)}{\partial \epsilon_{t}^{*}}=1-F\left(\epsilon_{t}^{*}\right)-\mu f\left(\epsilon_{t}^{*}\right) \epsilon_{t}^{*}
\end{gathered}
$$

Gives:

$$
\begin{gathered}
-g\left(z_{t}^{*}\right) Z_{t}+\lambda_{t}^{V}\left(\Delta\left(\epsilon_{t}^{*}\right)(1-\mu)+\mu f\left(\epsilon_{t}^{*}\right) \epsilon_{t}^{* 2}\right)=0 \\
\lambda_{t}^{V}=\frac{g\left(z_{t}^{*}\right) Z_{t}}{\Delta\left(\epsilon_{t}^{*}\right)(1-\mu)+\mu f\left(\epsilon_{t}^{*}\right) \epsilon_{t}^{* 2}}
\end{gathered}
$$

The first order condition of FIs' leverage and default threshold equate the tax benefit associated with a higher collateral value

$$
\lambda_{t}^{V}\left(\Delta\left(\epsilon_{t}^{*}\right)(1-\mu)+\mu f\left(\epsilon_{t}^{*}\right) \epsilon_{t}^{* 2}\right)
$$

with the expected loss of productivity associated with more intermediary defaults $g\left(z_{t}^{*}\right) Z_{t}$

$$
\begin{aligned}
\partial \Phi_{B, t}: E_{t}\left\{M_{t+1}[(\right. & \left(\left(1-F\left(\epsilon_{t}^{N}\right)\right)\left(1-G\left(z_{t+1}^{*}\right)\right)+\left(1-F\left(\epsilon_{t}^{N}\right)\right) G\left(z_{t+1}^{*}\right)\right)(1-\tau) \\
+ & \lambda_{t}^{B}\left(1-F\left(\epsilon_{t}^{N}\right)-\mu f\left(\epsilon_{t}^{N}\right) \epsilon_{t}^{N}\right)\left(1-G\left(z_{t+1}^{*}\right)\right)(1-\tau) \\
& +\lambda_{t}^{I}\left(1-F\left(\epsilon_{t}^{D}\right)-\mu f\left(\epsilon_{t}^{D}\right) \epsilon_{t}^{D}\right) G\left(z_{t+1}^{*}\right)\left(1-\mu_{B}\right) \\
& \left.\left.+\lambda_{t+1}^{V}\left(1-F\left(\varepsilon_{t}^{*}\right)-\mu f\left(\varepsilon_{t}^{*}\right) \varepsilon_{t}^{*}\right) k_{t}-A^{\prime}\left(\Phi_{B, t}\right)\right]\right\}
\end{aligned}
$$


Firms choose leverage by trading off the benefit of financial intermediation $\lambda_{t+1}^{V}\left(1-F\left(\epsilon_{t}^{*}\right)-\mu f\left(\epsilon_{t}^{*}\right) \epsilon_{t}^{*}\right)$ against the cost of default of nonfinancial firms $\mu f\left(\epsilon_{t}^{z}\right) \epsilon_{t}^{z}$ in different states of the world.

\section{Capital Gaps}

Following the financial accelerator literature, we assume that firms and FIs accumulate capital out of retained earnings, e.g., they take $n_{F, t}$ and $n_{B, t}$ as given. This is plausible as, for example, equity capital markets tend to narrow for issuers with declining earnings. The financial crisis has shown that this is particularly true for many banks that received emergency equity injections (in the form of preference shares) during the GFC.

The laws of motion for $n_{F, t}$ and $n_{B, t}$ are:

$$
n_{F, t}=\frac{R_{k, t}}{q_{t-1}}\left(n_{F, t-1}+n_{B, t-1}+d_{t-1}\right)\left(s_{F, t}^{N}\left(1-G\left(z_{t}^{*}\right)\right)+s_{F, t}^{D} G\left(z_{t}^{*}\right)\right)(1-\tau)\left(1-\gamma_{F}\right) z_{u, t}+\omega_{F}
$$

$$
n_{B, t}=\left(\frac{R_{k, t}}{q_{t-1}}\left(n_{F, t-1}+n_{B, t-1}+d_{t-1}\right) s_{B, t}^{N}-R_{d, t-1} d_{t-1}\right)\left(1-G\left(z_{t}^{*}\right)\right)(1-\tau)\left(1-\gamma_{B, t}\right) z_{k, t}+\omega_{B}
$$

Aggregating over all firms and FIs, firms and FIs inject earnings (see expected earnings in the Lagrangian function), minus equity payout captured by $\left(1-\gamma_{F}\right) z_{u, t}$ and $\left(1-\gamma_{B, t}\right) z_{k, t}$, plus a constant injection from households equal to $\omega_{F}$ and $\omega_{B}$. In general equilibrium, the laws of motion for $n_{F, t}$ and $n_{B, t}$ determine the tightness of the constraints or $\lambda_{t}^{I} \neq 1$ and $\lambda_{t}^{B} \neq 1$.

We calculate the potential levels (e.g., agents' target level) by choosing $n_{F, t}$ and $n_{B, t}$ optimally in addition to $d_{t}, R_{d, t}, z_{t+1}^{*}$ and $R_{b, t}$. Thus, the capital of firms and intermediaries, $n_{F, t}$ and $n_{B, t}$, are chosen in addition to $d_{t}$. The optimal solution implies:

$$
\lambda_{t}^{B}=\lambda_{t}^{I}=1
$$


Given that $\lambda_{t}^{I}=\lambda_{t}^{B}=1$ in the optimum, it has to be that welfare is higher than in the case when $\lambda_{t}^{I} \neq 1$ and/or $\lambda_{t}^{B} \neq 1$. The target levels are then compared to realized levels, and gaps are calculated. This is done for all variables of the model.

\section{Estimation}

The model is estimated with standard Bayesian estimation techniques developed by An and Schorfheide [2007]. The exogenous shocks fit the data by estimating the parameters of the model such that the model "optimally" matches the data; the measure of optimality is the likelihood of observing the realized data. We use four macro-economic and four financial variables to identify the main parameters of the model, as well as the exogenous shocks. The RBC model defined in this paper without financial frictions has four shock processes, and can be estimated, for example, with data for consumption, investment, output, and employment. Instead, we include four additional shock processes in our model, i.e., an idiosyncratic risk shock and aggregate risk shock, and a shock to the retained earnings/equity payout of both firms and FIs. We include four additional financial variables in our estimation: the corporate credit spread (hereafter CCS), the financial credit spread (hereafter FCS), bank Tier 1 capital, and stock prices.

Intermediary debt holders especially care about extreme events and aggregate risk because they are well diversified and not subject to idiosyncratic risk. This is confirmed by our model. Conditional on the intermediary default threshold $z_{t}^{*}$, financial spreads depend to a large extent on aggregate risk. As a result, changes in aggregate risk can be inferred from FCS through the pricing equation of intermediary debt. Similarly, conditional on aggregate risk, changes in credit risk can be inferred from CCS through the pricing equation of corporate debt. In the following section we will describe the data, the measurement equations, the calibrated parameters, and the parameters that will be estimated.

\subsection{Data}

The macroeconomic and financial variables that were used for the estimation are shown in Figure 12. The data cover the period between 2000Q1 to 2019Q2. The four macro-economic 
variables are real quarter-on-quarter percentage changes of GDP, investment, employment, and consumption, controlled first for population growth, and then demeaned, as in Smets and Wouters [2007] and Christiano, Motto, and Rostagno [2014]. GDP (dY), investment (dI), and consumption (dC) are taken from the Bureau of Economic Analysis. The data for investment is constructed as the sum of total fixed investment and durable consumption. The series for consumption is constructed as the sum of non-durable consumption and consumption services. Employment $(\mathrm{dN})$ and population growth are taken from the Bureau of Labor Statistics. The CCS is computed as the percentage difference between the iTraxx Industrial Corporate Bond Yield Index and the constant 10-year treasury maturity bond yield. The FCS is computed as the percentage difference between the iTraxx Financials Yield Index and the constant 10-year treasury maturity bond yield. The spreads are also demeaned. For the process of demeaning, the years 2008 and 2009 of the financial crisis were excluded. Total bank Tier 1 capital growth $(\mathrm{dnB})$ is the percentage change in Tier 1 capital of all Federal Deposit Insurance Institution (FDIC) insured commercial banks and savings institutions. These data come from FDIC and are demeaned and adjusted for inflation. Firm net worth growth $(\mathrm{dnF})$ is computed as the percentage change in the Down Jones 30 Stock Market Index, adjusted for inflation, and demeaned.

\subsection{Measurement equations}

The measurement equations link the observed variables to variables in the model. The measurement equations for the macroeconomic variables are trivial. Output, investment, employment, and consumption correspond one-to-one to each other. However, this raises questions about the extent to which credit spreads, Tier 1 bank capital, and share prices adequately reflect lending as well as funding conditions in the economy. We are concerned about overestimating the importance of shocks to FCS and retained earnings of firms and FIs; this might happen if, for example, some large intermediaries are funded mainly with deposits or benefit from government guarantees such that spreads are low even during crises. As such, funding costs implied by an index would overestimate their funding pressures. Consequently, we estimate the relationship between observed FCS $\left(F C S_{t}\right)$, observed CCS $\left(C C S_{t}\right)$, observed firms' equity growth $\left(d n F_{t}\right)$, and observed financial intermediary capital growth $\left(d n B_{t}\right)$ with their model 
counterparts by estimating sensitivity coefficients $1 / \kappa_{F}, 1 / \kappa_{C}, 1 / \kappa_{n F}$, and $1 / \kappa_{n B}$, which link the data (right-hand side) to the model variables (left-hand side):

$$
\begin{aligned}
& \left(E\left(R_{b, t+1}\right)-R_{t}-\left(R_{b, s s}-R_{s s}\right)\right) * 100=\frac{C C S_{t}}{\kappa_{C}} \\
& \left(E\left(R_{d, t+1}\right)-R_{t}-\left(R_{d, s s}-R_{s s}\right)\right) * 100=\frac{F C S_{t}}{\kappa_{F}} \\
& \left(\log \left(\frac{n_{F, t}}{n_{F, t-1}}\right)\right) * 100=\frac{d n F}{\kappa_{n F}} \\
& \left(\log \left(\frac{n_{B, t}}{n_{B, t-1}}\right)\right) * 100=\frac{d n B}{\kappa_{n B}}
\end{aligned}
$$

\subsection{Priors and posteriors}

The parameters of the model are split into two sets. The first set contains the calibrated parameters which are shown in Table 1. We choose standard values where possible. We choose $\mu=0.4$ such that the recovery value $1-\mu$ is close to the average recovery value of senior secured bonds (50 percent) and senior secured loans (70 percent), as reported by Moody's. To insure that taxation does not distort the model's results, we set the tax rate at $\tau=0.2$, the same as for capital gains. This is necessary because the tax rate not only affects net income but also capital gains. We set $z^{D}$ and $z^{N}$ close to the expected value of $z_{t+1}$ in the steady state, conditional on being above or below $z_{t+1}^{*}$, such that their dispersion does not exacerbate the response to aggregate risk shocks. Firms and financial intermediaries pay out a fraction of earning, $\gamma_{F}$ and $\gamma_{B}$, respectively, as dividends. We choose a higher payout for financial intermediaries, mimicking higher expected payout by investors; however, changes in the payout rates don't alter the results significantly.

We estimate four different sets of parameters: coefficients of auto correlation, standard deviations of the various shocks, parameters that fit the model to financial data ("financial parameters"), and parameters that govern adjustment costs. 


\section{Shock processes}

We define eight exogenous shocks: total factor productivity $z_{y, t}$, investment adjustment cost $z_{i, t}$, FIs' capital shock $z_{k, t}$, labor market tightening $z_{n, t}$, exogenous spending $z_{g, t}$, credit risk $\sigma_{\varepsilon, t}$, aggregate risk $\sigma_{z, t}$, and firms' income shock $z_{u, t}$. All shocks follow an auto-regressive process of order one:

$$
\begin{aligned}
& \ln \left(z_{y, t}\right)=\rho_{y} \ln \left(z_{y, t-1}\right)+\sigma_{y} e_{y, t} \\
& \ln \left(z_{i, t}\right)=\rho_{i} \ln \left(z_{i, t-1}\right)+\sigma_{i} e_{i, t} \\
& \ln \left(z_{k, t}\right)=\rho_{k} \ln \left(z_{k, t-1}\right)+\sigma_{k} e_{k, t} \\
& \ln \left(z_{n, t}\right)=\rho_{n} \ln \left(z_{n, t-1}\right)+\sigma_{n} e_{n, t} \\
& \ln \left(z_{g, t}\right)=\rho_{g} \ln \left(z_{g, t-1}\right)+\sigma_{g} e_{g, t} \\
& \ln \left(\sigma_{\varepsilon, t}\right)=\left(1-\rho_{\varepsilon}\right) \ln \left(\sigma_{\varepsilon, s s}\right)+\rho_{\varepsilon} \ln \left(\sigma_{\varepsilon, t-1}\right)+\sigma_{\varepsilon} e_{F, t} \\
& \ln \left(\sigma_{z, t}\right)=\left(1-\rho_{z}\right) \ln \left(\sigma_{z, s s}\right)+\rho_{z} \ln \left(\sigma_{z, t-1}\right)+\sigma_{\varepsilon} e_{B, t} \\
& \ln \left(z_{u, t}\right)=\rho_{u} \ln \left(z_{u, t-1}\right)+\sigma_{u} e_{u, t}
\end{aligned}
$$

The shocks $e_{j, t}$ are normally distributed. We estimate the auto correlation coefficients $\rho_{j}$ and the standard deviations $\sigma_{j}$ of the shocks.

\section{Financial and adjustment cost parameters.}

We estimate steady state credit risk and aggregate risk $\sigma_{\varepsilon, s s}$ and $\sigma_{z, s s}$, sensitivity coefficients $1 / \kappa_{F}, 1 / \kappa_{C}, 1 / \kappa_{n F}$, and $1 / \kappa_{n B}$, which link the data to the model variables, habit persistence parameter $h$ and adjustment cost coefficients $\Phi_{i}, k_{F, p}$, and $k_{B, p}$. 


\section{Results}

\subsection{Estimated parameter values}

Table 2 shows the prior mean and posterior mode of the estimated parameters, and distributional assumptions. In most cases, the standard deviation of the posterior distribution is less than half of the standard deviation of the prior distribution. This suggests that the posterior distributions incorporate a reasonable amount of the information from the data.

We notice that the financial shocks have the largest standard deviation indicating that financial variables are more volatile than real variables. The adjustment costs and habit formation play an important role in fitting the data. While the literature has highlighted the importance of habits and capital adjustment costs, costs of adjusting the capital structure of firms and FIs also play an important role. Interestingly, the cost of adjusting leverage is larger for intermediaries than firms. However, identification of leverage adjustment costs is weak, as the posterior standard deviation is close to the prior standard deviation.

As for the financial parameters, the steady-state credit risk is higher than steady-state aggregate risk, implying a lower probability of default, lower credit spreads, and higher leverage of FIs in comparison to firms in the neighborhood of the steady state. We set the prior of $\sigma_{\varepsilon, s s}$ equal to 0.23 such that the steady-state default probability of firms $P D^{F}\left(\varepsilon_{t+1}^{N}\right)$ is around 1.5 percent. Our prior is close to the posterior reported in Christiano, Motto, and Rostagno [2014] of 0.26. And indeed, the estimation procedure moves it closer toward that value, the posterior mode of $\sigma_{\varepsilon, s s}$ is 0.245 . Similar to firms, we set the prior of $\sigma_{z, s s}$ equal to 0.12 such that the steady-state default probability of financial institutions $P D^{B}\left(z_{t+1}^{*}\right)$ is around 0.75 percent (half of the firms's one); the estimation procedure brings it to 0.157. In general, obtaining a lower steady-state aggregate risk estimate than for credit risk is consistent with the fact that financial institutions are much higher levered than firms. Similarly, a lower steady-state default probability of financial institutions in comparison to firms is consistent with higher observed credit ratings. The iTraxx Industrials Corporate Bond Index is representative of a BBB-rated issuer, while financial institutions are rated AA on average, implying a higher default probability and a higher credit spread of firms in comparison to intermediaries.

We notice from the estimation of the sensitivity coefficients $\left(1 / \kappa_{F}, 1 / \kappa_{C}, 1 / \kappa_{n F}\right.$, and $\left.1 / \kappa_{n B}\right)$ 
that private sector data is a better match for the model than the financial intermediary one. In particular, changes in intermediaries' funding costs in the model amount to less than $12 \%$ $\left(1 / \kappa_{F}=0.12\right)$ of changes in observed FCS, probably due to deposit taking institutions and government sponsored enterprises for which funding costs don't oscillate strongly. Another interpretation is that the model has difficulties to match FCS during crisis episodes. It highlights the fact that the 2007-09 financial crisis was a tail event. CCS and the capital of firms and banks in the model correspond better to the data $\left(1 / \kappa_{C}=0.55 ; 1 / \kappa_{n F}=1.05 ; 1 / \kappa_{n B}=0.52\right)$.

\subsection{Main findings}

Since our framework includes both aggregate and corporate risk shocks, we first compare the impulse responses of selected real and financial variables to these shocks in Figure 2. The two shocks, which increase by $1 \%$ the probability of default of both FIs and firms, have qualitatively similar implications. As expected, positive aggregate and corporate risk shocks lead to a decrease in output, consumption, labor and investment while substantially increasing financial and corporate spreads. Following aggregate and idiosyncratic risk shocks, gaps in capital and probability of default of both FIs and firms rise as well, signaling an increase in financial and corporate leverage relative to the optimal values.

We next turn our attention to the five questions we posed in the introduction and we show how our framework can be employed to provide answers. To this purpose, we will focus on the historical shock decomposition of several strategic variables ${ }^{3}$. We first report results related to actual data to then present some of the model-produced outcomes, specifically the gaps (or deviations from the optimal values) in equity prices, firms' probability of default, and the capital of $\mathrm{FIs}^{4}$.

The first question we aimed to answer was: (i) What shocks have driven investment, CCS and FCS over the last 20 years? Figure 3 shows that developments in the investment growth rate are mainly caused by the equity price shock (brown bars), the risk shocks, both idiosyncratic (yellow bars) and aggregate (light blue bars), the TFP shock (dark blue bars) and the investment

\footnotetext{
${ }^{3}$ Historical decomposition is quantifying how much each structural shock explains in the historical fluctuations of the variables. By construction, the sum of the contribution of all shocks must equal the demeaned data, except for model estimation and approximation errors.

${ }^{4}$ We limit our attention to these variables for ease of exposition. Additional results are available in the Appendix or upon request.
} 
efficiency shock (red bars). Figures 4 and 5 show that CCS and FCS are mainly driven by the aggregate risk shocks and the firm's capital shocks. This finding is confirmed by the forecast error variance decomposition of the shocks reported in Table 3.

The second question was: (ii) How risky is the non-financial corporate sector and what explains these risks? Figure 6 shows the probability of default of firms; as expected, higher corporate risk is associated to the 2001 Dott-com bubble and the GFD; it is worth noticing that private sector risk has recently driven up the CCS.

The third question was: (iii) Are credit spreads and equity prices too high or too low? To asses the stability of the financial sector we analyzed the shock decomposition of the gaps in equity prices, corporate spreads, and FIs' capital. According to our model, corporate spreads are too low (Figure 7) while equity prices were too high prior to COVID-19 outbreak. This is illustrated in Figure 8, which attributes the high equity prices to a combination of corporate income shocks and risk shocks.

The fourth question was: (iv) How resilient is the banking sector against adverse shocks and what are the drivers? Figure 9 shows that banks capital buffers have recently declined due to equity payout. Three episodes stand out where more bank capital was needed, marked by a positive gap: prior to the Dott-com bubble, prior to the GFC, and in the recent period. The declining recent trend makes the FIs sector more vulnerable to adverse shocks, and should be of concern to policy makers.

\subsection{Counterfactual scenario}

Next, we perform a stress simulation scenario that will help us answer the fifth question, specifically: (v) Are banks more resilient given higher capital, or would deleveraging occur? Should the countercyclical buffer be activated?

The GFC marked the worst economic downturn during the period studied. Our stress test estimates the impact of a similar downturn on the U.S. economy today. For this, the structural shocks were reconstructed from historical time series. The shocks of the GFC during 2008-2011 were applied to simulate the macro stress test between 2019-2022.

Figure 10 shows the results of the macro stress test. The stress test shows that both banks and firms are more resilient to adverse shocks compared to the period prior to the GFC. 
However, FIs are found to be more vulnerable than firms at the current juncture, while both corporate and banking risk gaps are elevated under adverse conditions. Hence, if adverse shocks similar to GFC were to occur, deleveraging and severe recession would be expected. Fortunately, there is room to activate the countercyclical capital buffer.

\subsection{Policy implications of the analysis}

Whenever the analysis reveals risk and capital gaps, it implies that capital should be increased in the respective sector by earnings retention or issuance of equity. Alternatively, any policy measure could be used, as long as it closes capital and risk gaps -- and takes into consideration the general equilibrium effects. (Even though certain macroprudential tools are not part of the model they alter the observed data and hence change the gaps.) Consequently, the model can be used as a signaling device for macroprudential intervention (ex-ante and contemporaneous), and to gauge whether macroprudential action was successful (ex-post), e.g., whether gaps were closed. The analysis implies that more capital or macroprudential policy was needed before and/or during the three episodes: the Dott-com bubble (firm and FIs capital), the Global Financial Crisis (firm and FIs capital), and now (FIs capital). While banks have considerably strengthened their capital base, the countercyclical capital buffer could have been activated prior to the COVID-19 outbreak to guard against deleveraging in case of adverse shocks.

\subsection{Lessons for the COVID-19 episode}

The model and the counterfactual show that under adverse conditions, default risk in both corporate and financial sectors increase while corporate equity capital and bank capital will be scarce. This is already reflected in stock market losses following the outbreak of the COVID-19 pandemic. Going forward, this means that the cash flow of firms and banks will be further constrained. Firms and banks are well advised to stop paying dividends and build and sustain capital levels where possible to absorb future expected losses. This is especially true for banks that increased equity payout prior to the COVID-19 outbreak, as identified by the model as this will help prevent a crisis in the real economy turning into a financial crisis. Another lesson from the model is that capital (in firms and banks) addresses both solvency and liquidity concerns, 
and hence strengthens liquidity in the entire system.

\subsection{Evaluation of model's performance}

One of the main contributions of this article is to extend the framework of Christiano, Motto, and Rostagno [2014] to accommodate for default of FIs. A natural question that arises is to which extent our estimates of aggregate and credit risk are credible. To answer this question, in Figure 11 we compare two model implied proxies of aggregate uncertainty, namely the aggregate risk (described by equation 69) and the probability of default of FIs, with the measure of financial uncertainty proposed by Jurado, Ludvigson, and Ng [2015] and Ludvigson, Ma, and Ng [2015]. Both model based measures move reasonably close together with the financial uncertainty index considering that the empirical measure of financial uncertainty played no role in the model estimation ${ }^{5}$.

\section{Conclusion}

The financial turmoil experienced during the 2008 crisis propagated rapidly to the real economy with severe recessionary effects. This episode showed that a deeper understanding of the links between the financial sector and the real economy is a crucial ingredient for achieving and preserving financial and economic stability. To this end, we developed a general equilibrium model with two main features. First, the model captures sectoral dynamics of nonfinancial firms and financial intermediaries, the feedback between them, and the default risk in each sector. Second, the model provides a quantitative method for measuring gaps in risk and capital; specifically, the gaps are computed as deviations of realized values from targeted optimal values.

Our framework can be used to assess how capital and default risk of nonfinancial firms and financial intermediaries change over time and whether capital and risks are too low or too high at a given point in time. The tool we provide can be employed as a screening device for policymakers to indicate when to loosen or tighten macroprudential policy measures.

In an application to the U.S. economy, we aimed at answering the following questions: (i) What shocks have driven investment, CCS, and FCS over the last 20 years?, (ii) How risky

\footnotetext{
${ }^{5}$ In Figure 15 we show that the model based measure of FIs probability of default is highly correlated as well with the macroeconmic uncertainty measure of Jurado, Ludvigson, and Ng [2015]
} 
is the non-financial corporate sector and what explains these risks?, (iii) Are credit spreads and equity prices too high or too low?, (iv) How resilient is the banking sector against adverse shocks and what are the drivers?, (v) Stress simulation: Given higher capital, would banks be more resilient if the GFC was replayed between 2019-2022, or would deleveraging occur? And should countercyclical buffers be activated?

According to our estimates, both idiosyncratic and systemic risk shocks are important drivers of investment, CCS, and FCS. Capital of firms and FIs were too low during the Dottcom bubble and the GFC, and it has been recently declining for FIs. In addition, corporate spreads were too low while the equity prices were too high prior to COVID-19 outbreak; this finding is explained by a combination of corporate income shocks and risk shocks. Finally, the stress test analysis reveals that FIs are more vulnerable than firms at the current juncture, while both corporate and banking risk gaps are elevated under adverse conditions. Under an adverse scenario similar to GFC, deleveraging and severe recession are anticipated.

Regarding the outbreak of COVID-19, we plan to re-estimate the model once the data of 2020Q1 and Q2 become available and discuss the findings in a separate application. It would be interesting to find out whether the market response of credit spreads and equity prices was adequate. Other interesting extensions would be to introduce nominal rigidities, and/or heterogenous firms and FIs. Furthermore, a relaxation of macroprudential policy when systemic risk materializes (i.e., aggregate risk is increasing) could be analyzed by modeling it as a positive net equity shock to banks against the backdrop of a negative shock to aggregate risk. It would be also interesting to see the effects with and without a relaxation of capital. 
Figure 2: Impulse responses to aggregate and corporate risk shocks.
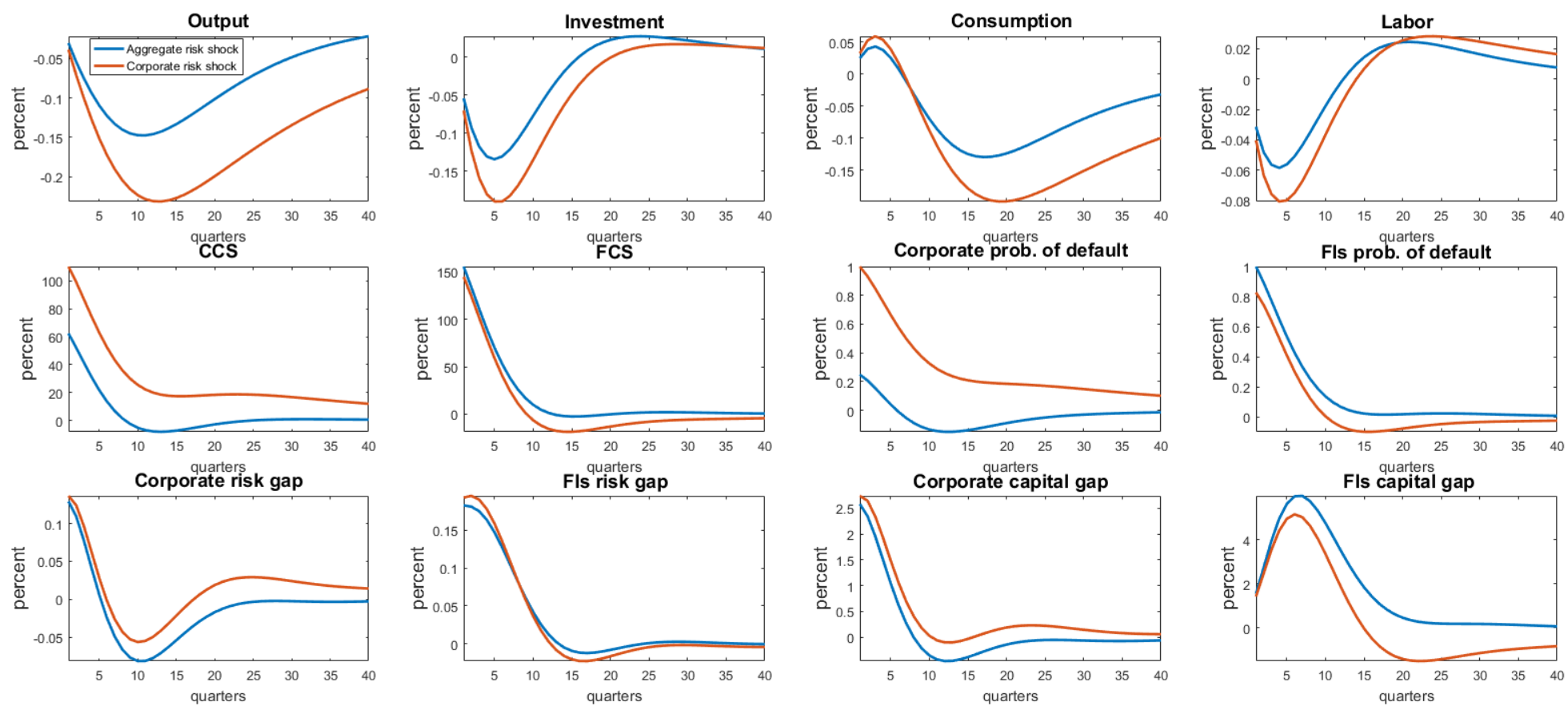

The $\mathrm{x}$-axis denotes forecasting horizon. The $\mathrm{y}$-axis denotes percentages. Responses are scaled to increase FIs and respectively corporate risk (probability of default) by $1 \%$ on impact.

Figure 3: Historical decomposition of investment growth rate

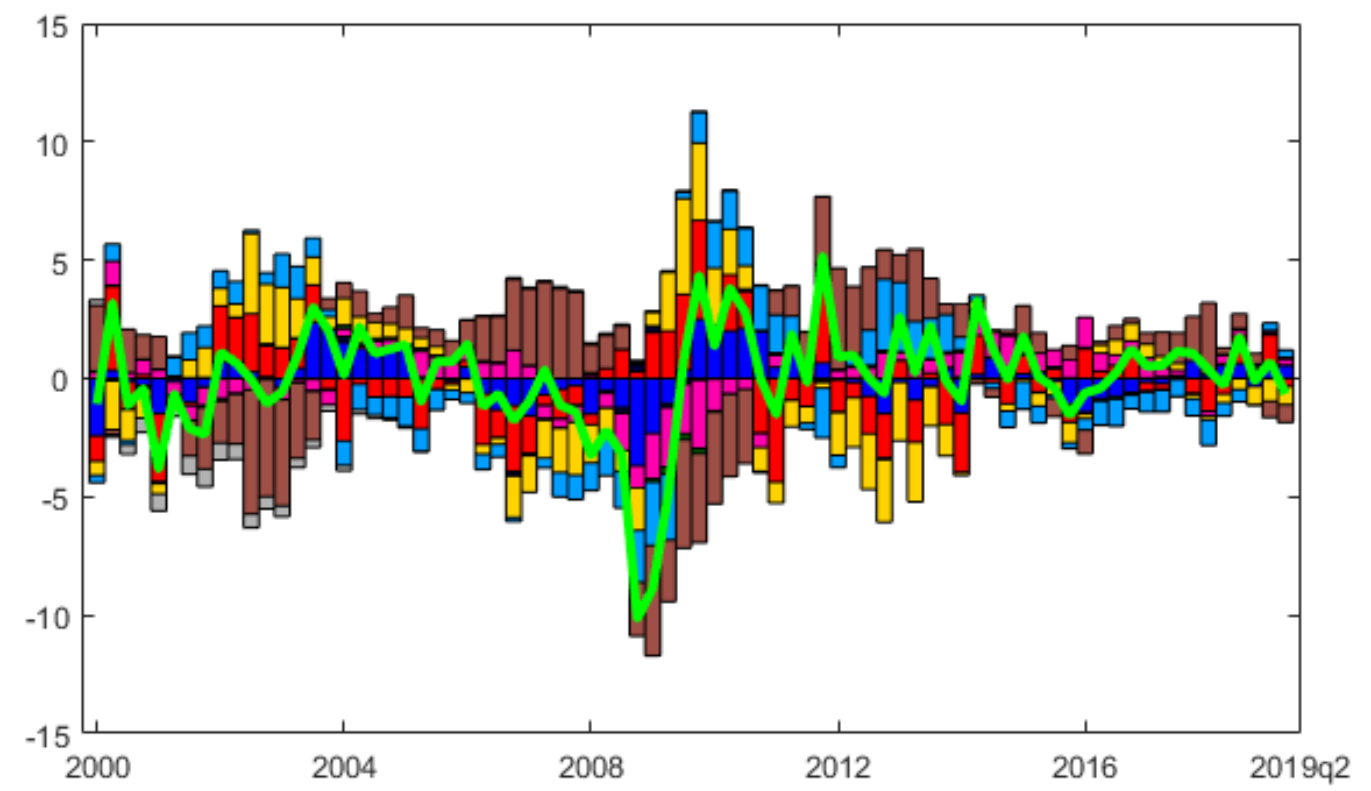

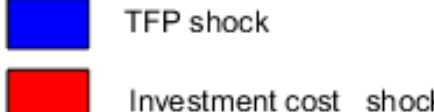

Fls capital shock

$\square$ Labor market shock

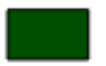

Government spending shock

Credit risk shock

Aggregate risk shock

Firms's capital shock

Initial values

The $\mathrm{x}$-axis denotes the year. The y-axis denotes percentage points. A value of 4 indicates that the investment growth rate is $4 \%$. 
Figure 4: Historical decomposition of corporate credit spreads
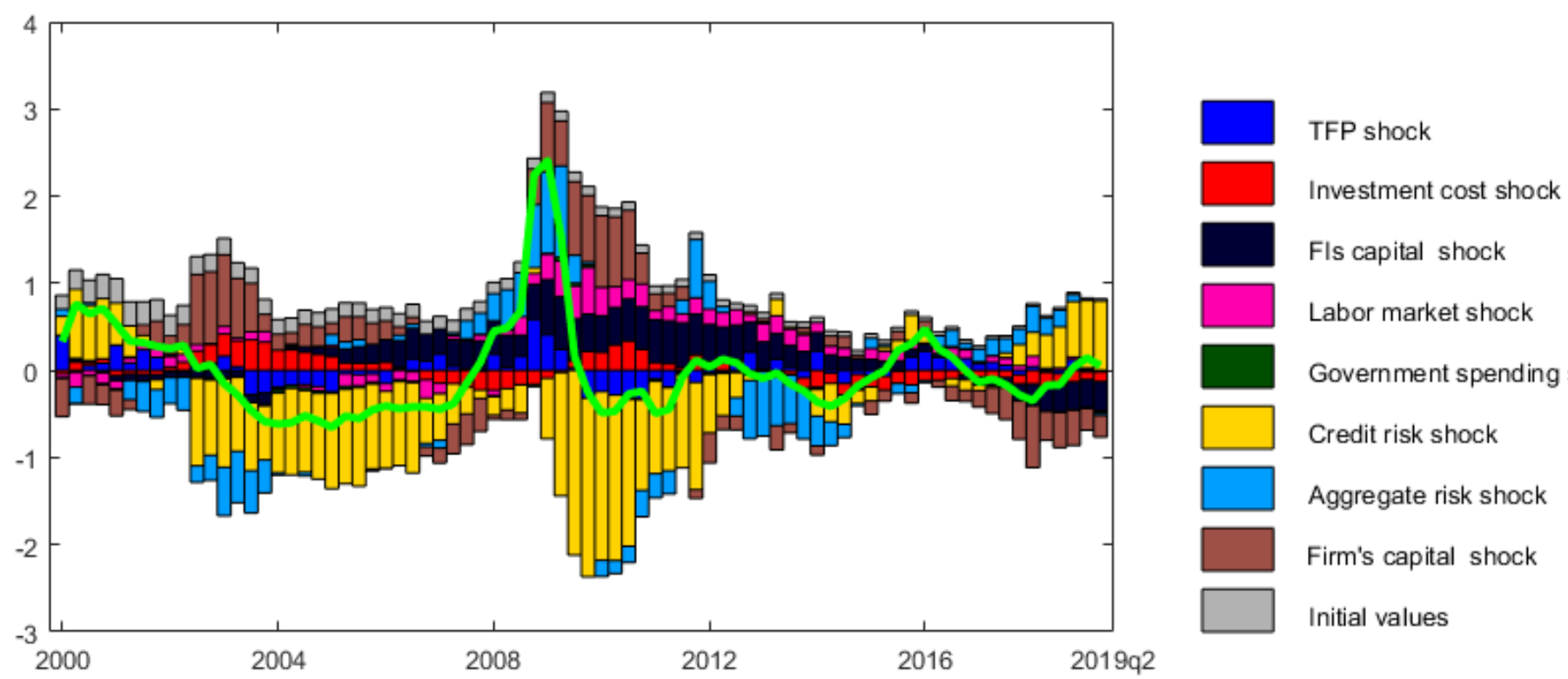

Government spending shock

Credit risk shock

Aggregate risk shock

Firm's capital shock

Initial values

The $\mathrm{x}$-axis denotes the year. The $\mathrm{y}$-axis denotes percentage points. A value of 4 indicates that the corporate credit spread is $4 \%$.

Figure 5: Historical decomposition of financial credit spreads
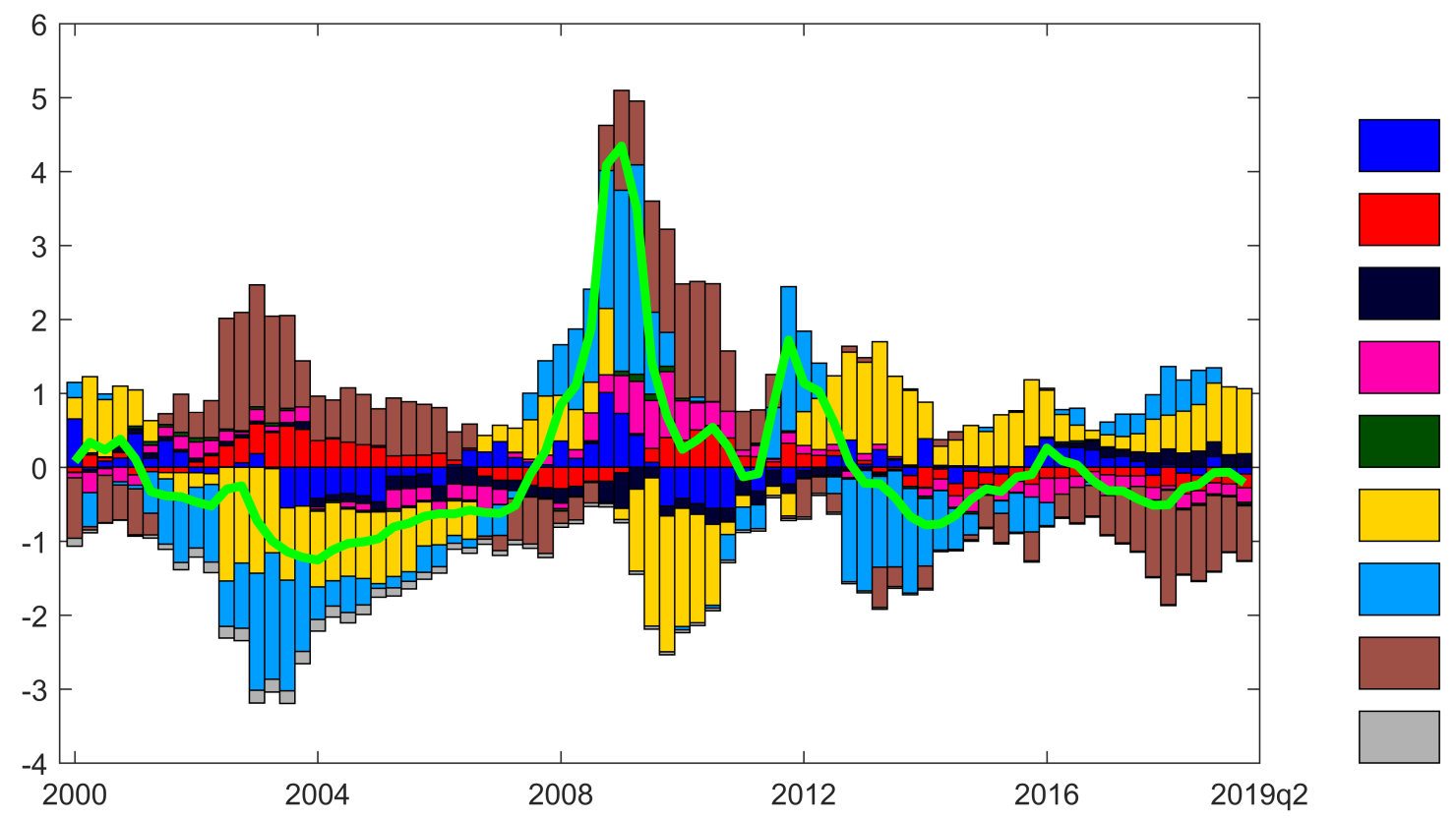

TFP shock

Investment cost shock

Fls capital shock

Labor market shock

Government spending shock

Credit risk shock

Aggregate risk shock

Firms's capital shock

Initial values

The $\mathrm{x}$-axis denotes the year. The y-axis denotes percentage points. A value of 4 indicates that the financial credit spread is $4 \%$. 
Figure 6: Historical decomposition of firms' probability of default

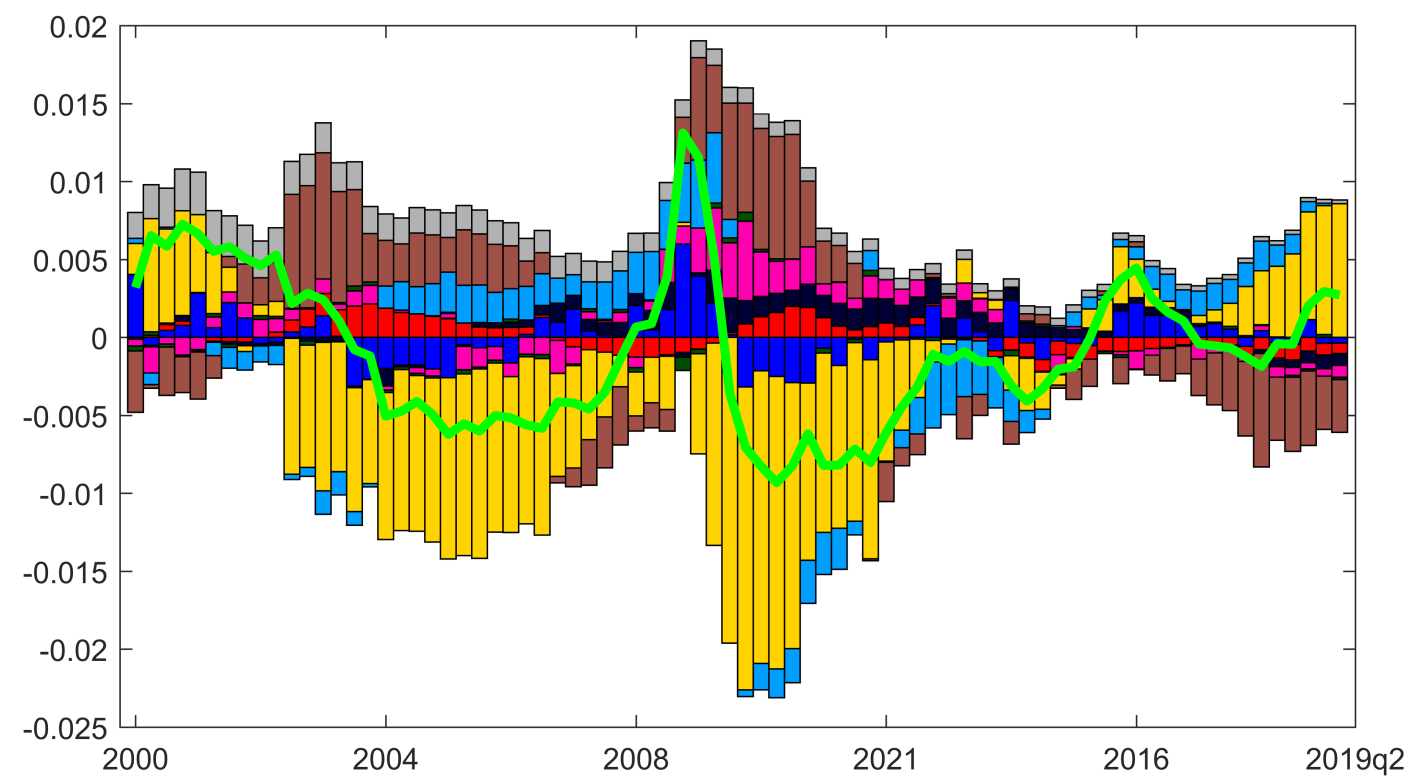

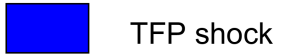

Investment cost shock

Fls capital shock

Labor market shock

Government spending shock

Credit risk shock

Aggregate risk shock

Firm's capital shock

Initial values

The $\mathrm{x}$-axis denotes the year. The y-axis denotes percentage points. A value of 0.015 indicates that firm's probability of default is $1.5 \%$

Figure 7: Historical decomposition of the gap in corporate spread.

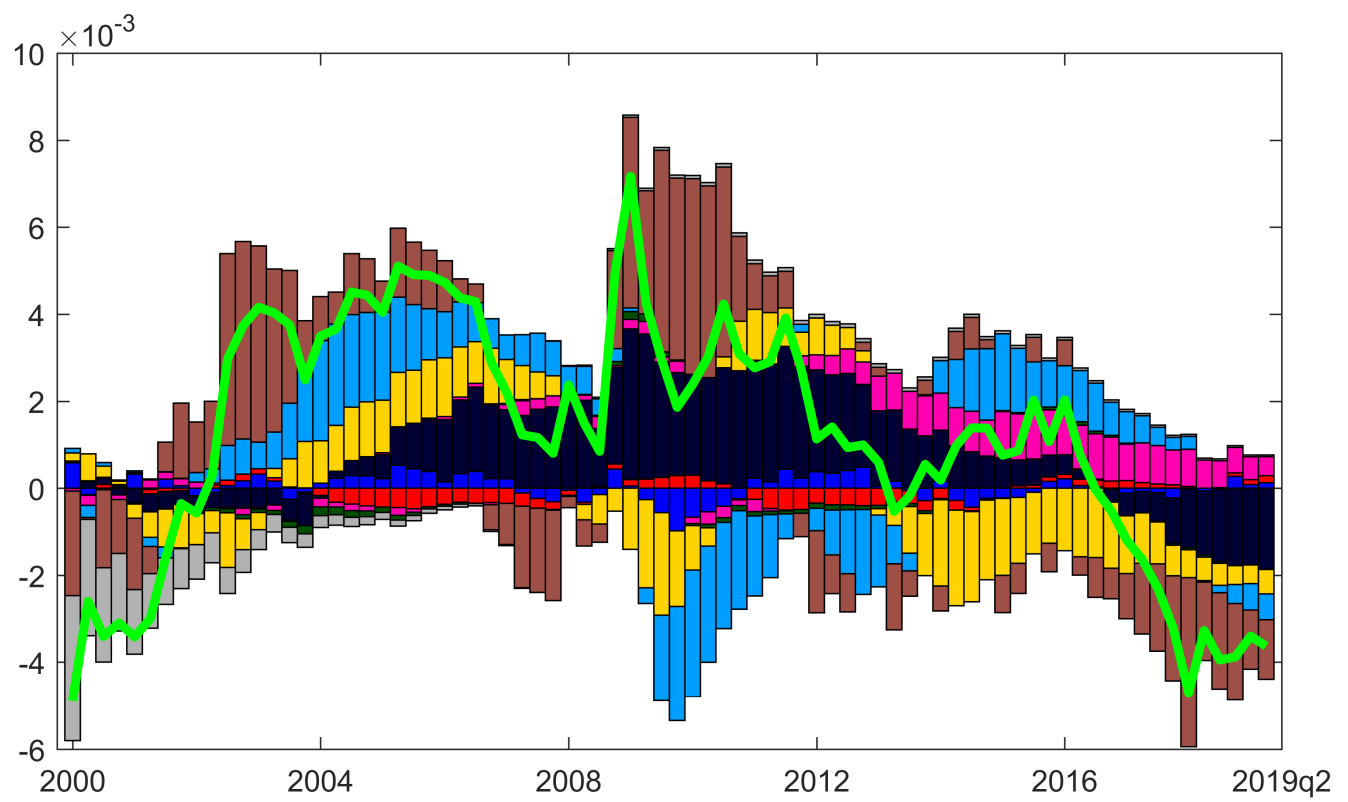

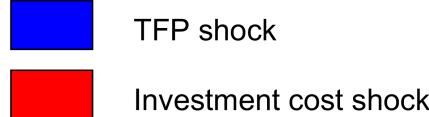

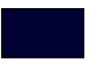

Fls capital shock
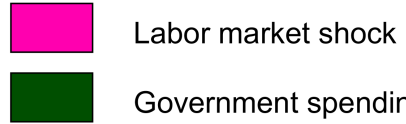

Government spending shock

Credit risk shock

Agrgegate risk shock

Firm's capital shock

Initial values

Gaps are computed as realized values less the optimal as follows: Gap $=($ Spread - Spread Optimal $)$. The x-axis denotes the year. The y-axis denotes percentage point. 0.008 indicates that corporate spreads are higher than the optimal values implied by the model by $0.8 \%$. 
Figure 8: Historical decomposition of the gap in asset prices.

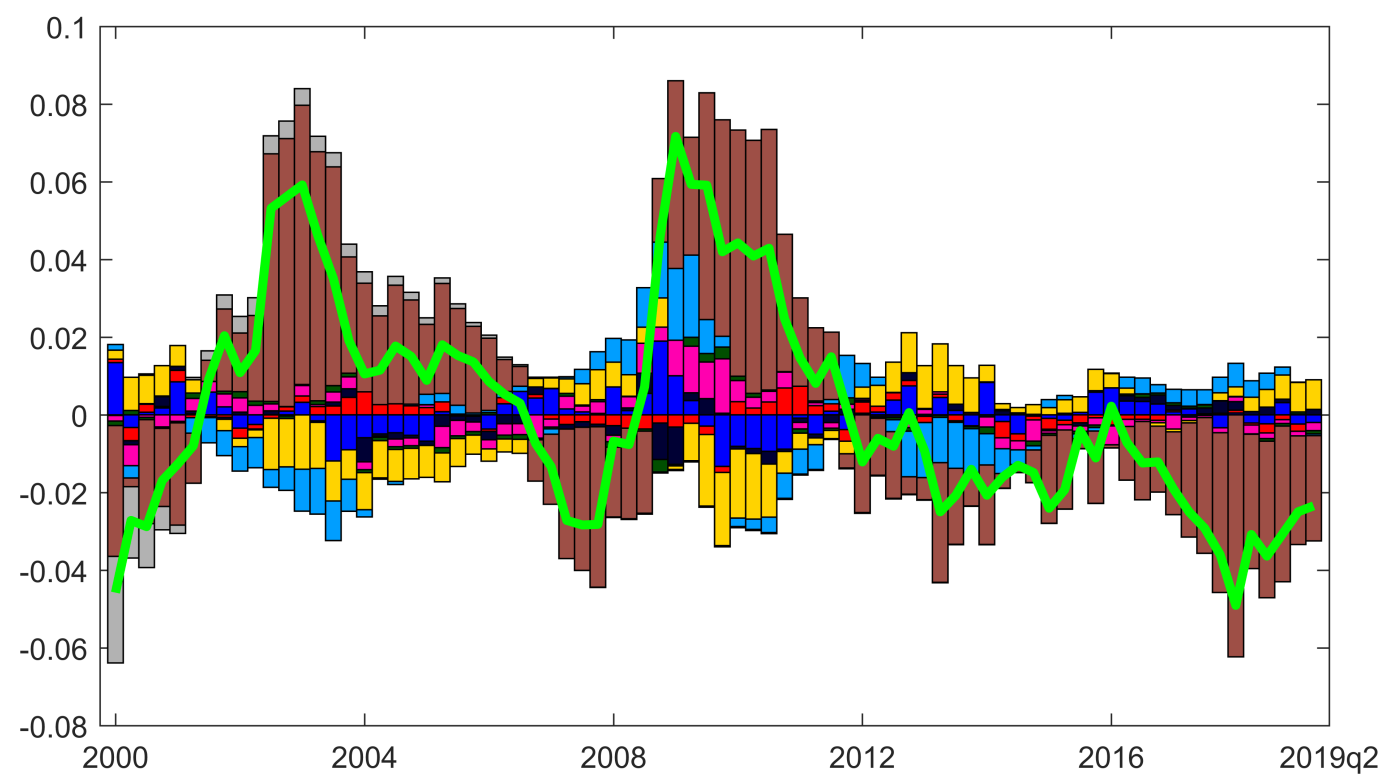

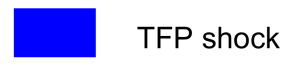

Investment cost shock

Fls capital shock

Labor market shock

Government spending shock

$\square$ Credit risk shock

Aggregate risk shock

Firm's capital shock

Initial values

Gaps are computed as optimal values less realized values as follows: Gap $=\left(q_{\text {Optimal }}-q\right) / q$, where $q$ denotes the asset prices. The $\mathrm{x}$-axis denotes the year. The y-axis denotes percentages. 0.1 indicates that the asset prices are $10 \%$ lower than the optimal values predicted by the model.

Figure 9: Historical decomposition of the gap of bank's capital.

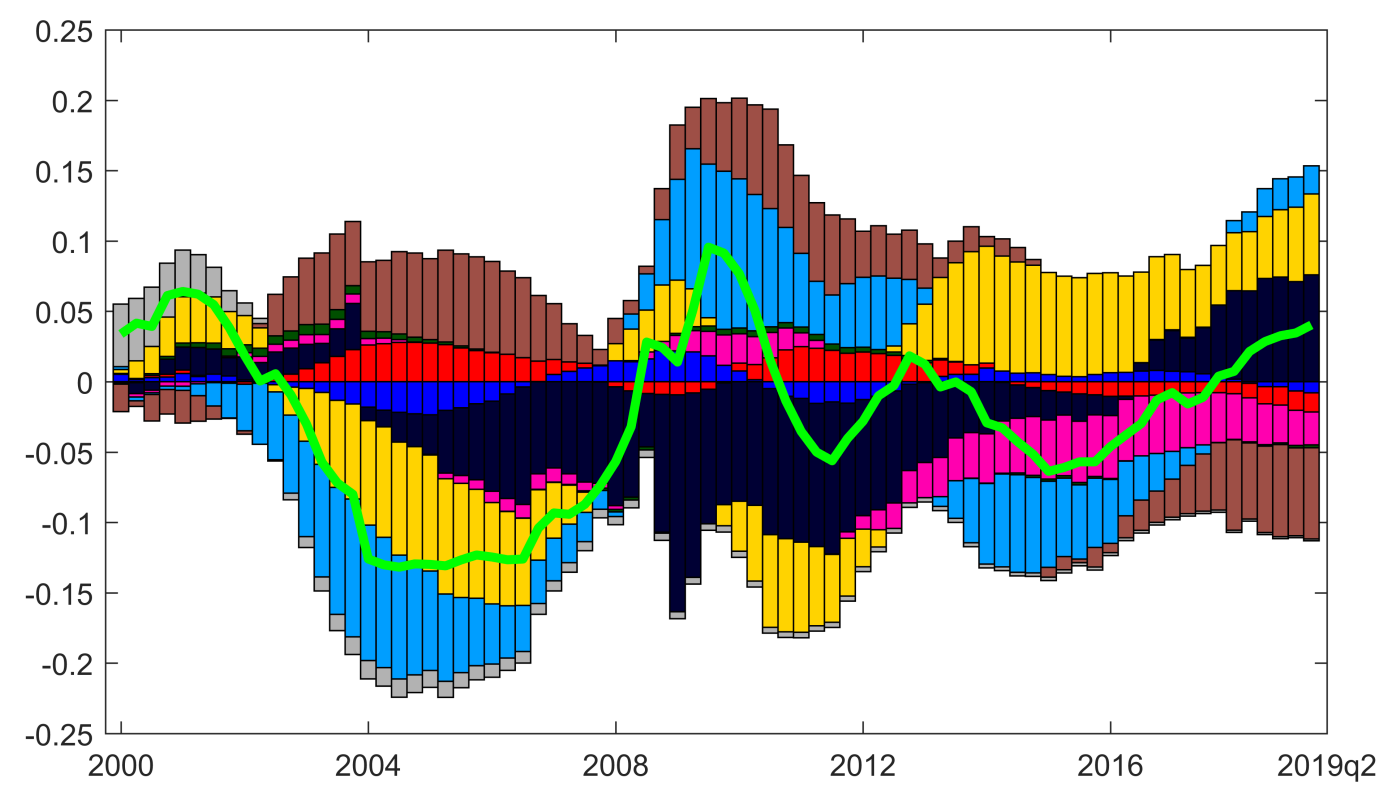

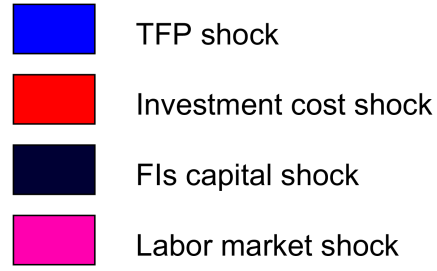

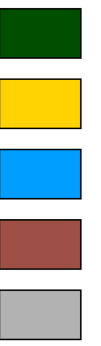

Government spending shock

Credit risk shock

Aggregate risk shock

Firm's capital shock

Initial values

Gaps are computed as optimal values less realized values as follows: $G a p=\left(n B_{\text {Optimal }}-n B\right) / n B$, where $n B$ denotes the bank capital. The $\mathrm{x}$-axis denotes the year. The y-axis denotes percentages. 0.2 is equal to a 20 percent gap relative to the nominal amount of aggregate bank's capital. 
Figure 10: Counterfactual scenario
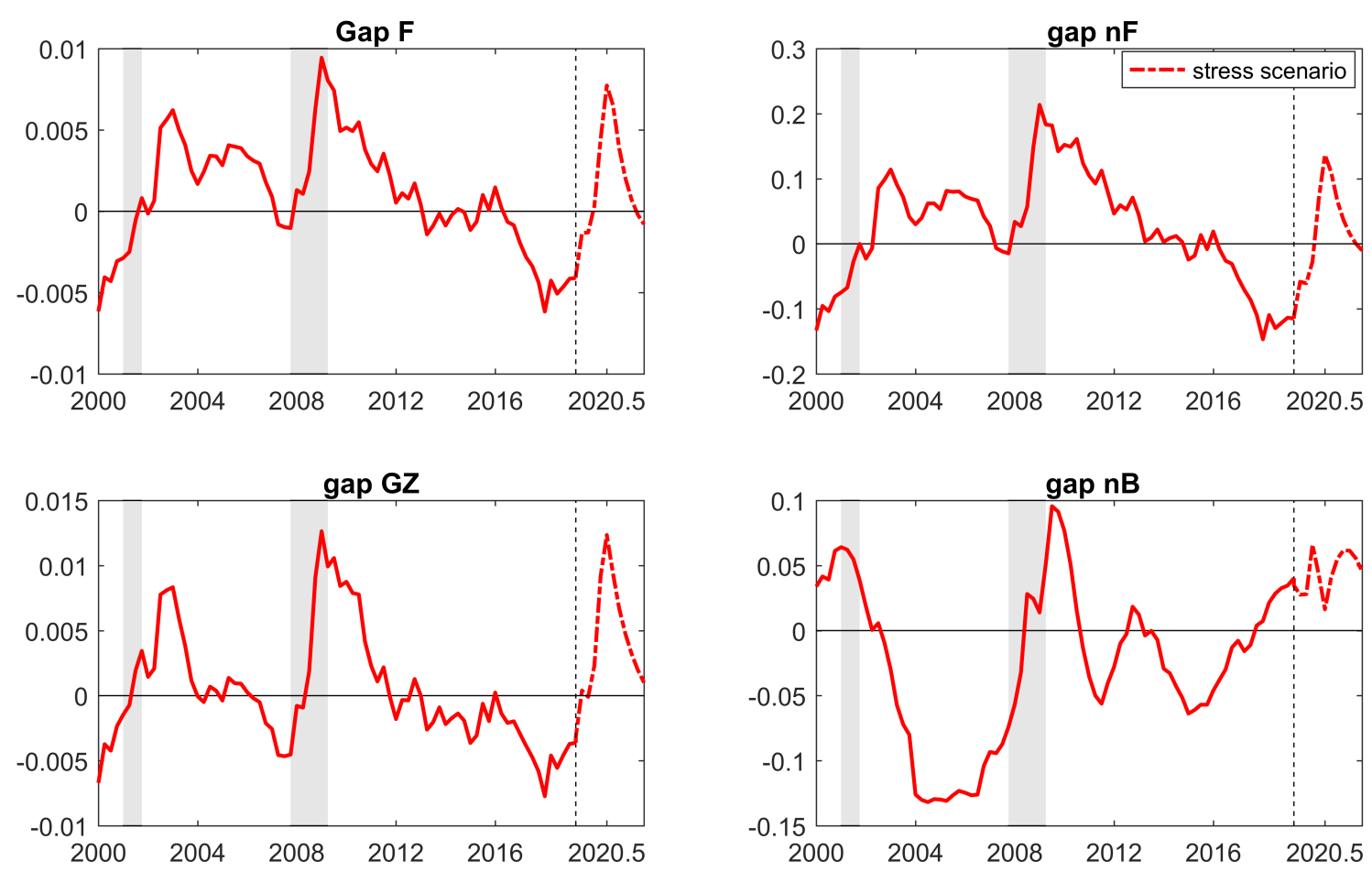

The figure shows gaps of default risk and aggregate capital of the nonfinancial corporate sector and the banking sector. Gaps are computed as optimal values less realized values. The $\mathrm{x}$-axis denotes the year. The y-axis denotes percentages (in the case of risk, 0.005 is equal to 0.5 percent excessive default risk in absolute terms; in the case of capital, 0.2 is equal to a 20 percent gap relative to the nominal amount of aggregate capital). The grey bars highlight recession periods of U.S. economy. The dotted red line simulates a crisis period that is similar in magnitude to the GFC. 
Figure 11: Model based systemic risk (blue line) and FIs prob. of default (green line) vs. Ludvigson et al. 2015 Financial Uncertainty (red line).

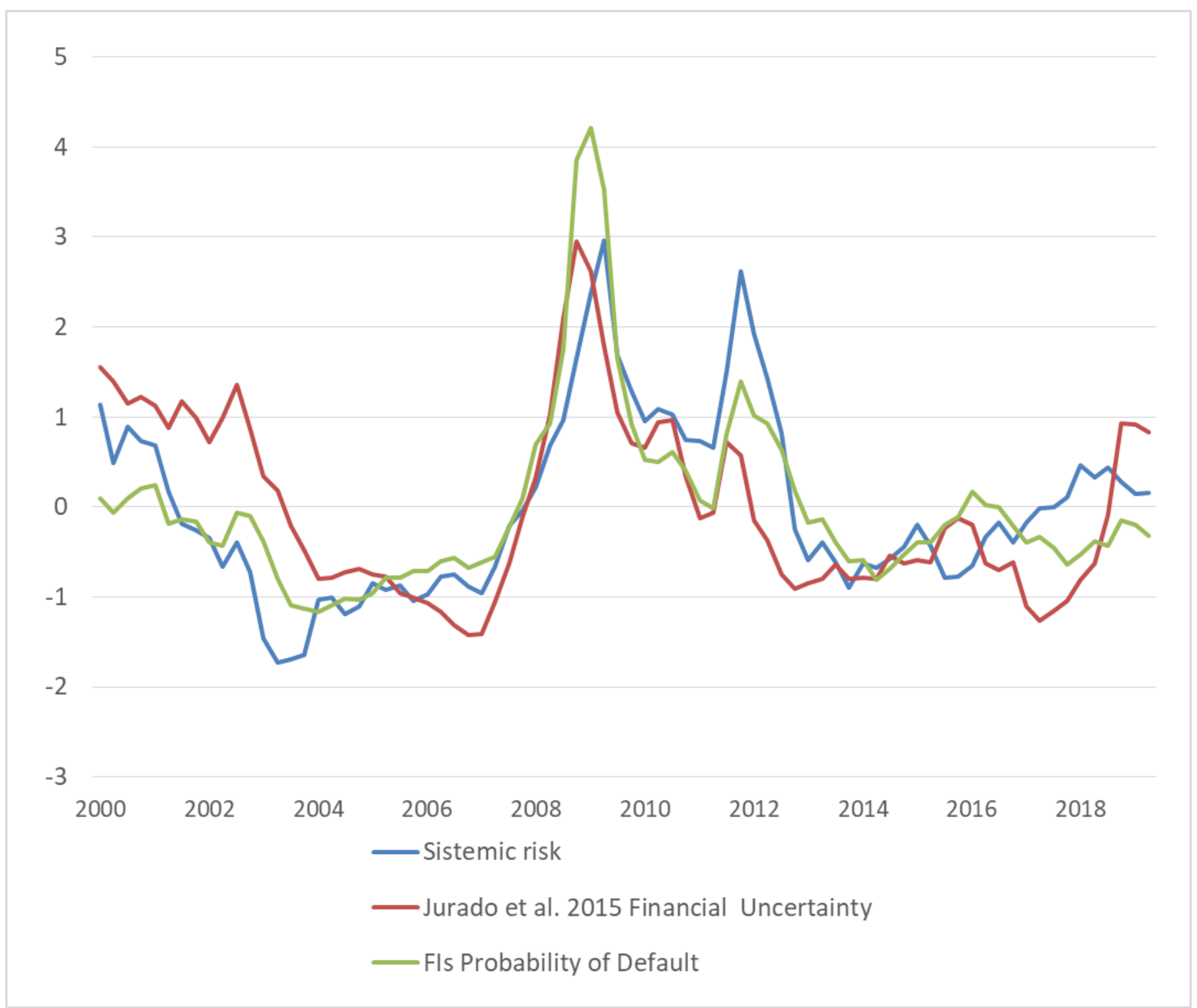

The $\mathrm{x}$-axis denotes the year. The y-axis denotes percentage points. A value of 4 corresponds to a level of uncertainty/prob. of default of $4 \%$. All variables are standardized. 


\section{References}

Adrian, T. and N. Boyarchenko. 2012. "Intermediary leverage cycles and financial stability". Becker Friedman Institute for Research in Economics Working Paper (2012-010).

An, S. and F. Schorfheide. 2007. "Bayesian analysis of dsge models". Econometric reviews $26(2-4), 113-172$.

Angeloni, I. and E. Faia. 2013. "Capital regulation and monetary policy with fragile banks". Journal of Monetary Economics 60(3), 311-324.

Begenau, J. and T. Landvoigt. 2018. "Financial regulation in a quantitative model of the modern banking system". Available at SSRN 2748206 .

Benes, J. and M. Kumhof. 2011. "Risky bank lending and optimal capital adequacy regulation". IMF working paper 11-130, International Monetary Fund, Washington, DC.

Benigno, G., H. Chen, C. Otrok, A. Rebucci, and E. R. Young. 2013. "Financial crises and macro-prudential policies". Journal of International Economics 89(2), 453-470.

Bernanke, B., M. Gertler, and S. Gilchrist. 1998. "The financial accelerator in a quantitative business cycle framework". Technical report, National Bureau of Economic Research, Cambridge, MA.

Bianchi, J. and E. G. Mendoza. 2018. "Optimal time-consistent macroprudential policy". Journal of Political Economy 126(2), 588-634.

Bloom, N. 2009. "The impact of uncertainty shocks". Econometrica 77(3), 623-685.

Bloom, N., M. Floetotto, N. Jaimovich, I. Saporta-Eksten, and S. J. Terry. 2018. "Really uncertain business cycles". Econometrica 86(3), 1031-1065.

Brunnermeier, M. K. and Y. Sannikov. 2014. "A macroeconomic model with a financial sector". American Economic Review 104(2), 379-421.

Christiano, L. J., R. Motto, and M. Rostagno. 2014. "Risk shocks". American Economic Review 104(1), 27-65. 
Diamond, D. W. and P. H. Dybvig. 1983. "Bank runs, deposit insurance, and liquidity". Journal of political economy 91(3), 401-419.

Gertler, M. and N. Kiyotaki. 2010. "Financial intermediation and credit policy in business cycle analysis". In "Handbook of monetary economics", volume 3, pages 547-599. Amsterdam: Elsevier.

Gertler, M. and N. Kiyotaki. 2015. "Banking, liquidity, and bank runs in an infinite horizon economy". American Economic Review 105(7), 2011-43.

Gertler, M., N. Kiyotaki, and A. Prestipino. 2019. "Credit booms, financial crises and macroprudential policy". Working Paper.

Gertler, M., N. Kiyotaki, and A. Queralto. 2012. "Financial crises, bank risk exposure and government financial policy". Journal of Monetary Economics 59, S17-S34.

Gilchrist, S., J. W. Sim, and E. Zakrajšek. 2014. "Uncertainty, financial frictions, and investment dynamics". Technical report, National Bureau of Economic Research.

Gourio, F. 2013. "Credit risk and disaster risk". American Economic Journal: Macroeconomics $5(3), 1-34$.

Gourio, F., A. K. Kashyap, and J. W. Sim. 2018. "The trade offs in leaning against the wind". IMF Economic Review 66(1), 70-115.

He, Z. and A. Krishnamurthy. 2012. "A model of capital and crises". The Review of Economic Studies 79(2), 735-777.

He, Z. and A. Krishnamurthy. 2013. "Intermediary asset pricing”. American Economic Review $103(2), 732-70$.

Hirakata, N., N. Sudo, and K. Ueda. 2011. "Do banking shocks matter for the us economy?" Journal of Economic Dynamics and Control 35(12), 2042-2063.

Hirakata, N., N. Sudo, and K. Ueda. 2013. "Is the net worth of financial intermediaries more important than that of non-financial firms?" Globalization and Monetary Policy Institute Working Papers 161, Federal Reserve Bank of Dallas. 
Jeanne, O. and A. Korinek. 2014. "Macroprudential policy beyond banking regulation". Financial Stability Review (18), 163-172.

Jermann, U. and V. Quadrini. 2012. "Macroeconomic effects of financial shocks". American Economic Review 102(1), 238-71.

Jin, Y. and Z. Zeng. 2011. The Financial and Macroeconomic Implications of Banking Frictions and Banking Riskiness. Department of Economics, Monash University.

Jurado, K., S. C. Ludvigson, and S. Ng. 2015. "Measuring uncertainty". American Economic Review 105(3), 1177-1216.

Kehoe, P. and V. Midrigan. 2015. "Prices are sticky after all". Journal of Monetary Economics $75,35-53$.

Kiyotaki, N. and J. Moore. 1997. "Credit cycles". Journal of political economy 105(2), 211-248.

Krasa, S. and A. P. Villamil. 1992. "Monitoring the monitor: an incentive structure for a financial intermediary". Journal of Economic Theory 57(1), 197-221.

Lorenzoni, G. 2008. "Inefficient credit booms". The Review of Economic Studies 75(3), 809-833.

Ludvigson, S. C., S. Ma, and S. Ng. 2015. "Uncertainty and business cycles: exogenous impulse or endogenous response?" Technical report, National Bureau of Economic Research.

Nuño, G. and C. Thomas. 2017. "Bank leverage cycles". American Economic Journal: Macroeconomics $9(2), 32-72$.

Olafsson, T. T. 2018. "Cross-border credit intermediation and domestic liquidity provision in a small open economy". International Monetary Fund.

Smets, F. and R. Wouters. 2007. "Shocks and frictions in us business cycles: A bayesian dsge approach". American Economic Review 97(3), 586-606.

Zeng, Z. 2013. "A theory of the non-neutrality of money with banking frictions and bank recapitalization". Economic Theory 52(2), 729-754. 


\section{A Additional results}

The forecast error variance decomposition for selected variables is reported in Table 3. Results show that credit risk and systemic risk shocks explain an important share of the investment dynamics, specifically $16.3 \%$ and $9.3 \%$. Unsurprisingly, the credit risk shock also explains the largest share in the variation of the CCS and the firm's probability of default $(\mathrm{F})$, while the aggregate risk shock is the main driver of the forecast variation in the FCS and the FIs' probability of default (GZ). The shock to firm's income turns out to explain most of the variation in the firm's capital (59.5\%) and a substantial share in investment (36\%), CCS (16.12\%), FCS (26.81\%), F (18.62\%) and GZ (28.27\%). As expected, the shock to FIs' capital is the main driver of the fluctuations in FIs' capital (40\%) together with the credit risk shock $(20.26 \%)$ and firm's capital shock (20\%). The risk shocks explain little in consumption which is driven mainly by the TFP and labor market tightening shocks. We would expect that once the model is estimated using a New-Keynesian framework with sticky prices and sticky wages, the residual shocks loose further relevance, and the risk shocks become even more important. We leave the estimation of such a New-Keynesian model for future research.

Tables 1 and 2 report the calibrated and estimated parameters of the model, while Figures 13 and14 show the historical shock decomposition of the gap in firms' capital and the FIs' probability of default. Recently, firms have capital higher than optimal, similar to the period prior to the Dott-com bubble, while banks display a low probability of default prior to COVID19 crisis. Figure 12 plots the transformed variables used in the estimation stage.

Finally, Figure 15 compares our model based measure of FIs probability of default with the empirical macroeconomic uncertainty measure of Jurado, Ludvigson, and Ng [2015]. The two measures are shown to be highly correlated. 
Table 1: Calibrated parameters values

\begin{tabular}{ccc}
\hline Parameters & Description & Values \\
\hline \hline$\alpha$ & power on capital in production function & 0.300 \\
$\beta$ & discount factor & 0.990 \\
$\delta$ & depreciation rate of capital & 0.025 \\
$\mu$ & firm's cost of default & 0.400 \\
$\mu_{B}$ & financial intermediary cost of default & 0.200 \\
$\tau$ & overall tax rate & 0.200 \\
$\gamma_{F}$ & firm equity payout rate & 0.030 \\
$\gamma_{B}$ & financial intermediary equity payout rate & 0.100 \\
$z^{D}$ & productivity during a crisis & 0.700 \\
$z^{N}$ & productivity in normal times & 1.010 \\
\hline \hline
\end{tabular}

Figure 12: Variables used in the estimation step. Shaded areas represent NBER recessions.

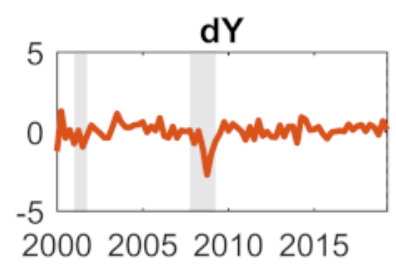

Year

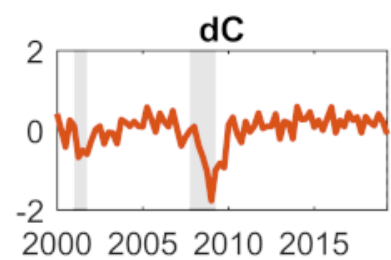

Year

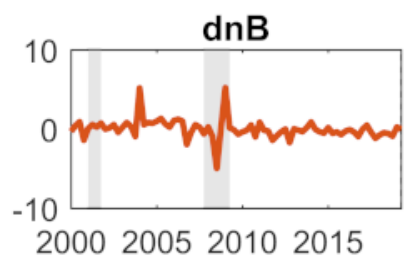

Year dl

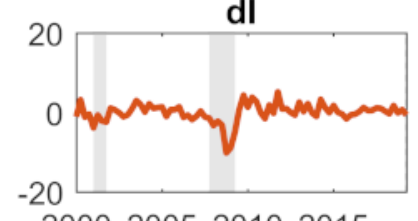

2000200520102015

Year

FCS

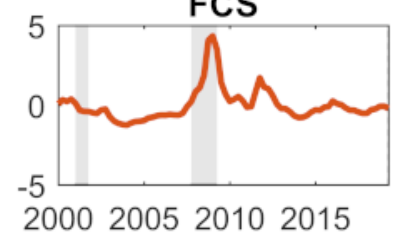

Year

dnF

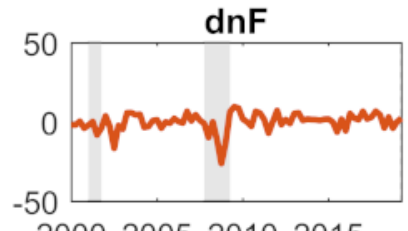

2000200520102015

Year

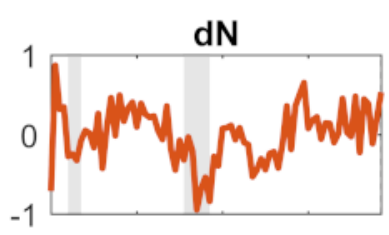

2000200520102015

Year

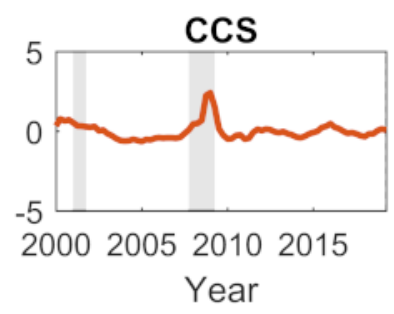


Table 2: Estimated parameters values

\begin{tabular}{|c|c|c|c|c|c|c|}
\hline Parameters & Description & Prior mean & Post. mode & Post. SD & Distr. & Prior SD \\
\hline$\rho_{y}$ & autocorr. of TFP shock & 0.9 & 0.9537 & 0.0238 & beta & 0.0500 \\
\hline$\rho_{i}$ & autocorr. of investment shock & 0.9 & 0.6983 & 0.0637 & beta & 0.0500 \\
\hline$\rho_{g}$ & autocorr. of gov spending shock & 0.9 & 0.9337 & 0.0393 & beta & 0.0500 \\
\hline$\rho_{n}$ & autocorr. of labor disutility shock & 0.9 & 0.9643 & 0.0161 & beta & 0.0500 \\
\hline$\rho_{u}$ & autocorr. of firm' capital shock & 0.9 & 0.8575 & 0.0268 & beta & 0.0500 \\
\hline$\rho_{k}$ & autocorr. of FIs' capital shock & 0.5 & 0.2965 & 0.0947 & beta & 0.2000 \\
\hline$\rho_{F}$ & autocorr. of credit risk shock & 0.5 & 0.9605 & 0.0150 & beta & 0.2000 \\
\hline$\rho_{B}$ & autocorr. of aggregate risk shock & 0.5 & 0.9293 & 0.0311 & beta & 0.2000 \\
\hline$\sigma_{y}$ & SD of TFP shock & 0.01 & 0.0080 & 0.0006 & invg & 0.0020 \\
\hline$\sigma_{i}$ & SD of investment shock & 0.01 & 0.0269 & 0.0039 & invg & 0.0020 \\
\hline$\sigma_{g}$ & SD of gov. spending shock & 0.01 & 0.0170 & 0.0013 & invg & 0.0020 \\
\hline$\sigma_{n}$ & SD of labor disutility & 0.01 & 0.0096 & 0.0008 & invg & 0.0020 \\
\hline$\sigma_{k}$ & SD of FIs capital shock & 0.01 & 0.0140 & 0.0019 & invg & 0.0020 \\
\hline$\sigma_{u}$ & SD of firms' capital shock & 0.01 & 0.0070 & 0.0007 & invg & 0.0020 \\
\hline$\sigma_{F}$ & SD of credit risk shock & 0.01 & 0.0199 & 0.0026 & invg & 0.0020 \\
\hline$\sigma_{B}$ & SD of aggregate risk shock & 0.01 & 0.0227 & 0.0028 & invg & 0.0020 \\
\hline$\sigma_{F s s}$ & steady state credit risk & 0.230 & 0.2449 & 0.0122 & norm & 0.0200 \\
\hline$\sigma_{B s s}$ & steady state aggregate risk & 0.120 & 0.1570 & 0.0111 & norm & 0.0200 \\
\hline$\kappa_{C}$ & inverse sensitivity to CCS & 3.000 & 1.8201 & 0.1993 & norm & 1.0000 \\
\hline$\kappa_{F}$ & inverse sensitivity to FCS & 6.000 & 8.4630 & 0.7039 & norm & 1.0000 \\
\hline$\kappa_{n F}$ & inverse sensitivity to $d n F$ & 1.000 & 0.9501 & 0.1297 & norm & 1.0000 \\
\hline$\kappa_{n B}$ & inverse sensitivity to $d n_{B}$ & 4.000 & 1.9324 & 0.1838 & norm & 1.0000 \\
\hline$\Phi_{i}$ & investment adjustment cost & 1.000 & 3.1199 & 0.5663 & norm & 1.0000 \\
\hline$h$ & habit in consumption & 0.500 & 0.4811 & 0.0537 & norm & 0.2000 \\
\hline$\kappa_{F p}$ & firm leverage adjustment cost & 0.050 & 0.0552 & 0.0214 & norm & 0.0250 \\
\hline$\kappa_{B p}$ & FIs leverage adjustment cost & 0.050 & 0.0754 & 0.0200 & norm & 0.0250 \\
\hline
\end{tabular}


Table 3: Forecast error variance decomposition of selected variables

\begin{tabular}{ccccccccc}
\hline Variance decomp (\%) & TFP & Investment & FIs capital & Labor mkt. & Gov. spending & Credit risk & Agg. risk & Firm's capital \\
\hline \hline output & 58.42 & 1.42 & 0.00 & 27.53 & 2.69 & 3.95 & 1.42 & 4.56 \\
investment & 16.32 & 15.46 & 0.04 & 6.38 & 0.07 & 16.3 & 9.29 & 36.13 \\
consumption & 57.63 & 1.41 & 0.00 & 27.69 & 4.06 & 3.50 & 1.33 & 4.37 \\
labor & 5.0 & 0.97 & 0.00 & 78.53 & 12.09 & 0.84 & 0.51 & 2.05 \\
CCS & 8.28 & 4.40 & 7.08 & 3.07 & 0.07 & 49.72 & 11.26 & 16.12 \\
FCS & 6.99 & 4.61 & 1.14 & 2.39 & 0.07 & 23.83 & 34.16 & 26.81 \\
Firm' pr. of default (F) & 7.34 & 2.15 & 0.99 & 2.52 & 0.08 & 63.11 & 5.19 & 18.62 \\
FIs' pr. of default (GZ) & 10.02 & 2.67 & 0.83 & 3.39 & 0.13 & 19.07 & 35.63 & 28.27 \\
FIs capital (dnB) & 11.26 & 0.18 & 39.90 & 3.76 & 0.36 & 20.26 & 4.23 & 20.05 \\
Firms capital (dnF) & 21.31 & 0.76 & 1.13 & 7.15 & 0.54 & 4.74 & 4.88 & 59.49 \\
\hline \hline
\end{tabular}

Figure 13: Historical decomposition of gap in corporate capital.

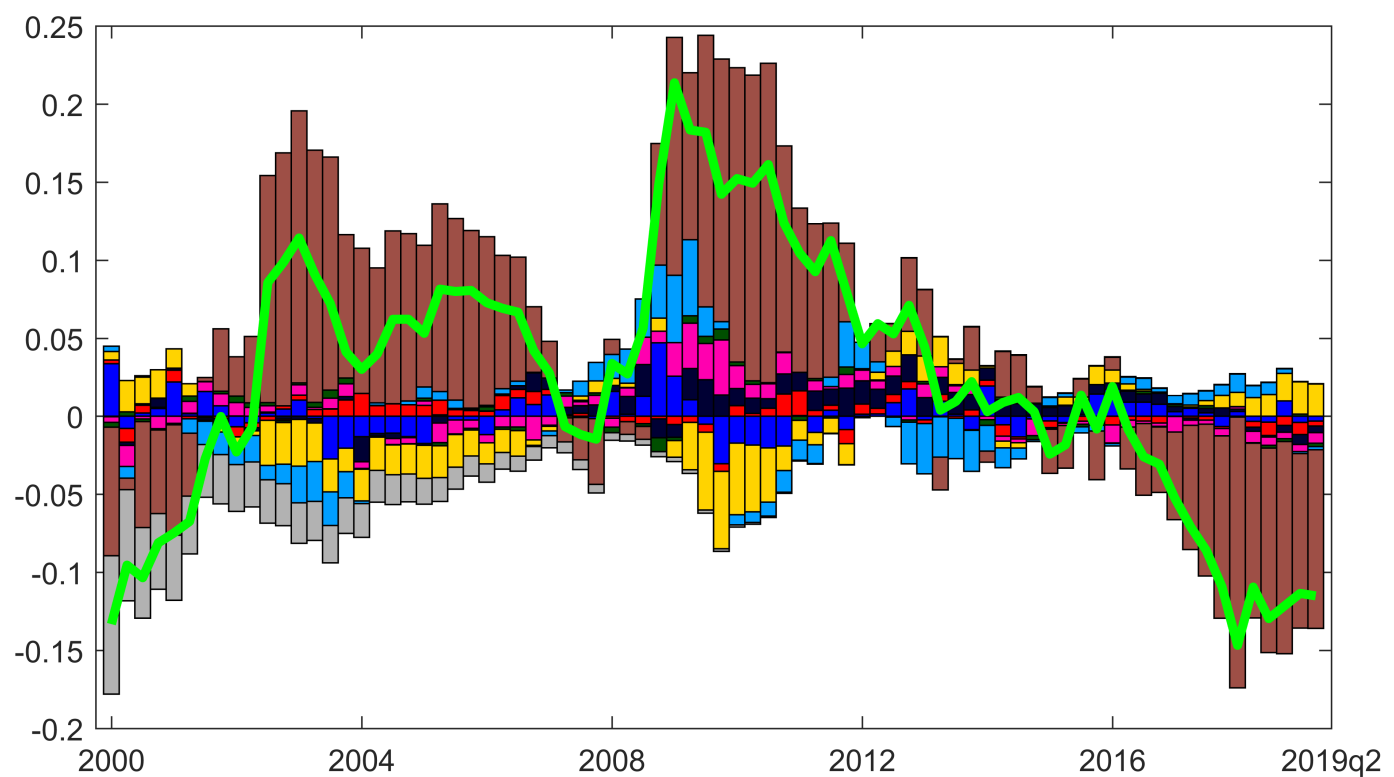

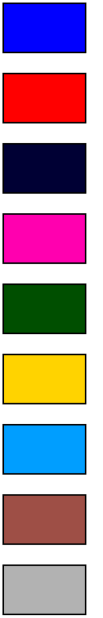

TFP shock

Investment cost shock

Fls capital shock

Labor market shock

Government spending shock

Credit risk shock

Aggregate risk shock

Firm's capital shock

Initial values

Gaps are computed as optimal values less realized values as follows: $G a p=\left(n F_{\text {Optimal }}-n F\right) / n F$ where $n F$ denotes the corporate capital. The $\mathrm{x}$-axis denotes the year. The $\mathrm{y}$-axis denotes percentages. 0.2 is equal to a 20 percent gap relative to the nominal amount of aggregate firm's capital. 
Figure 14: Historical decomposition of FIs' probability of default
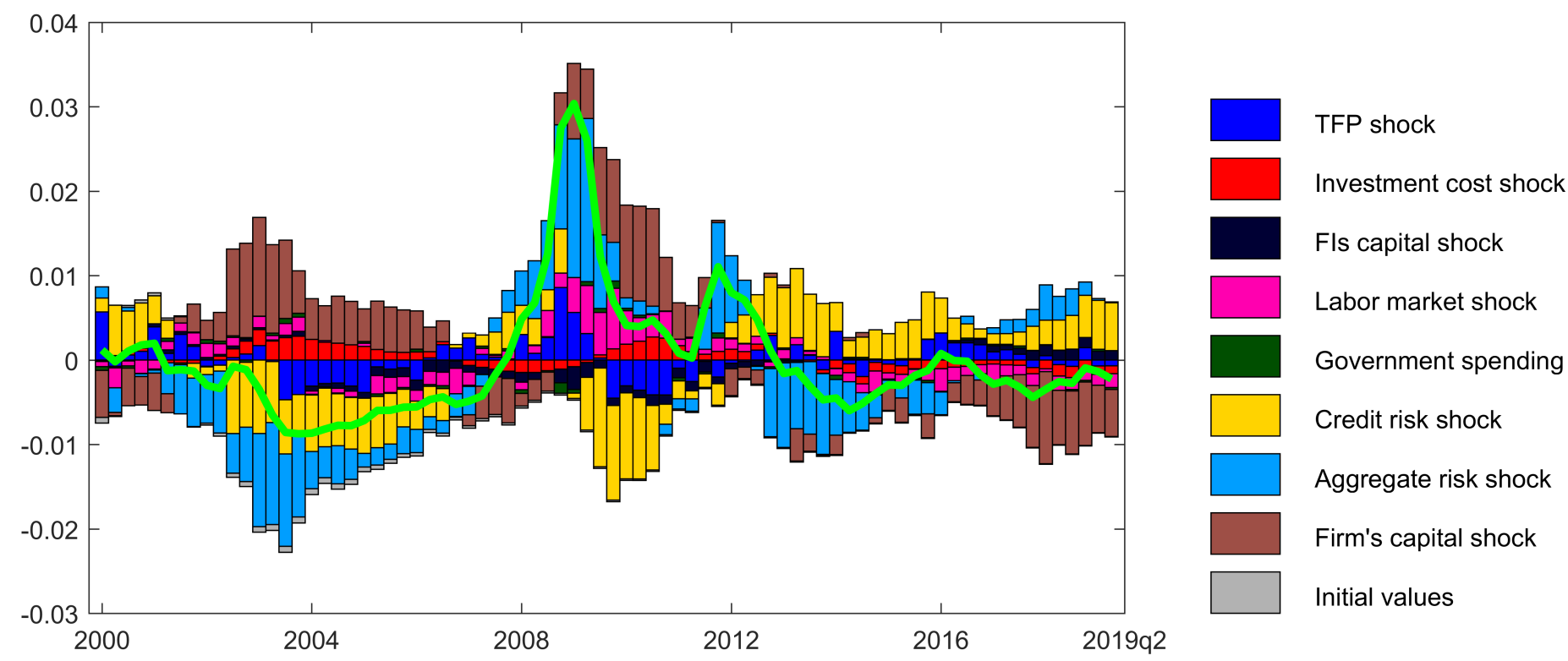

Government spending shock Credit risk shock

Aggregate risk shock

Firm's capital shock

Initial values

The $\mathrm{x}$-axis denotes the year. The $\mathrm{y}$-axis denotes percentage points. A value of 0.04 indicates that FIs' probability of default is $4 \%$. 
Figure 15: FIs prob. of default (red line) vs. Jurado et al. 2015 Macroeconomic Uncertainty (blue line). All variables are standardized.

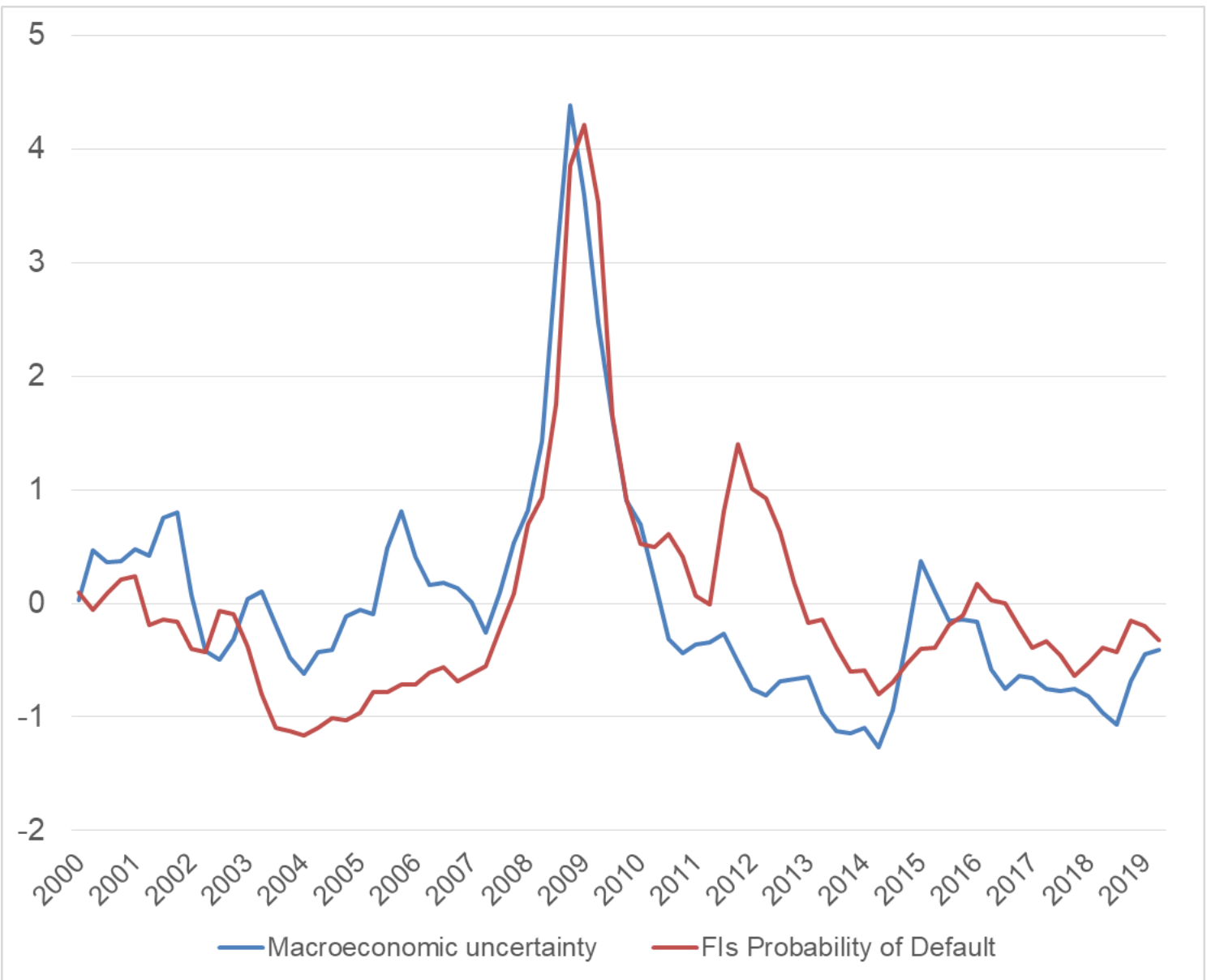

The $\mathrm{x}$-axis denotes the year. The $\mathrm{y}$-axis denotes percentage points. A value of 4 corresponds to a level of uncertainty/prob. of default of $4 \%$. All variables are standardized. 